\title{
Opioid Receptor Probes Derived from Cycloaddition of the Hallucinogen Natural Product Salvinorin A
}

\author{
Anthony Lozama, ${ }^{\ddagger}$ Christopher W. Cunningham, ${ }^{\S}$ Michael J. Caspers, ${ }_{\S}^{\S}$ Justin T. Douglas, ${ }^{\perp}$ \\ Christina M. Dersch," Richard B. Rothman," and Thomas E. Prisinzano, ${ }^{*}$, \\ ${ }^{\ddagger}$ Division of Medicinal \& Natural Products Chemistry, University of Iowa, Iowa City, Iowa 52242, United States \\ ${ }^{\S}$ Department of Medicinal Chemistry, University of Kansas, Lawrence, Kansas 66045, United States \\ ${ }^{\perp}$ Molecular Structures Group, University of Kansas, Lawrence, Kansas \\ "Clinical Psychopharmacology Section, IRP, NIDA, DHHS, Baltimore, Maryland 21224, United States
}

Supporting Information

ABSTRACT: As part of our continuing efforts toward more fully understanding the structure-activity relationships of the neoclerodane diterpene salvinorin $\mathrm{A}$, we report the synthesis and biological characterization of unique cycloadducts through $[4+2]$ Diels - Alder cycloaddition. Microwave-assisted methods were developed and successfully employed, aiding in functionalizing the chemically sensitive salvinorin $\mathrm{A}$

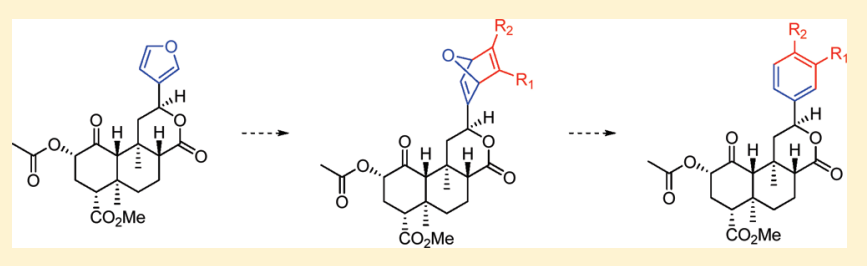
scaffold. This demonstrates the first reported results for both cycloaddition of the furan ring and functionalization via microwaveassisted methodology of the salvinorin A skeleton. The cycloadducts yielded herein introduce electron-withdrawing substituents and bulky aromatic groups into the $\mathrm{C}-12$ position. Kappa opioid (KOP) receptor space was explored through aromatization of the bent oxanorbornadiene system possessed by the cycloadducts to a planar phenyl ring system. Although dimethyl- and diethylcarboxylate analogues $\mathbf{5}$ and $\mathbf{6}$ retain some affinity and selectivity for KOP receptors and are full agonists, their aromatized counterparts 13 and 14 have reduced affinity for KOP receptors. The methods developed herein signify a novel approach toward rapidly probing the structure-activity relationships of furan-containing natural products.

Salvia divinorum Epling \& Játiva (Lamiaceae) is a hallucino$\checkmark$ genic mint species found in Oaxaca, Mexico, and recently in parts of California. Traditionally, S. divinorum has been used by the natives of Oaxaca for their divination ceremonies, along with the treatment of headaches, rheumatism, and abdominal swelling. ${ }^{1}$ The main active component of $S$. divinorum has been identified as the neoclerodane diterpene salvinorin A (1). ${ }^{2,3}$ While many neoclerodane diterpenes have been found to possess biological activity, 1 was found to be a potent hallucinogen in humans with an active dose between 200 and $500 \mu \mathrm{g}$. ${ }^{4}$ Furthermore, 1 was found to be a full agonist at $\kappa$-opioid (KOP) receptors despite having no structural similarity to other known KOP receptor ligands, such as the benzomorphinan cyclazocine or the arylacetamide U50,488. ${ }^{5}$ The potential for abuse has led to the regulation of S. divinorum and $\mathbf{1}$ in several U.S. states and a growing number of countries abroad. However, the unique characteristics of $\mathbf{1}$ have also helped spark significant scientific interest as well. Even though $\mathbf{1}$ is a potent hallucinogen, it does not have any affinity for the $5-\mathrm{HT}_{2 \mathrm{~A}}$ receptor, ${ }^{5}$ which is the target receptor for classical hallucinogens such as LSD, mescaline, and psilocin. Experiments with $\mathbf{1}$ in rats have demonstrated that $\mathbf{1}$ can block the locomotor effects of cocaine ${ }^{6,7}$ along with having opioidmediated antinociceptive properties, ${ }^{8,9}$ providing evidence for the potential utility of $\mathbf{1}$ and related analogues as stimulant abuse therapeutics and analgesics. On the basis of the potential therapeutic applications, we and others have begun to investigate the structure-activity relationships (SAR) of $1 .^{10-12}$

To date, the majority of analogues of 1 prepared and evaluated have explored the role of the C- 2 acetoxy group. These investigations have found that the appropriate substituent in this position may alter selectivity for opioid receptors (2), as well as increase potency and extend duration of action in vivo ( 3 and 4$).{ }^{13-15}$ By comparison, the role of the furan ring is less understood. Additional studies are necessary due to the implication of the furan ring in binding at KOP receptors by several modeling studies, ${ }^{16,17}$ as well as the potential for furan-containing natural products to be hepatotoxic upon bioactivation by various CYP450 enzymes. ${ }^{18-23}$ In an effort to circumvent potential hepatotoxicity and provide further insight into the SAR of $\mathbf{1}$, furan-modified analogues were sought.

In the development of additional SAR for the furan ring present in 1, two approaches were considered. The first approach considered was the incorporation of conformational constraint. This strategy is often a fruitful technique and has been used previously for the interactions of natural products at receptors. ${ }^{24}$ In our case this approach is synthetically challenging and would

Received: October 30, 2010

Published: February 21, 2011 


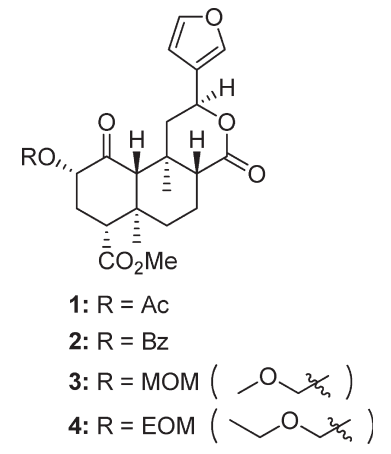

require the development of a new or modification of an existing synthesis of $1 ;^{25,26}$ thus this approach was not undertaken. The alternative approach followed was to incorporate additional steric bulk directly to the natural product. This approach has been used successfully with opium alkaloids ${ }^{27}$ and is particularly informative in cases where the X-ray crystal structure of a given molecular target, such as the KOP receptor, is unavailable. Furthermore, this approach was expected to provide details in a more timely manner.

Furan rings have demonstrated themselves as versatile building blocks for the construction of molecules in semi- and total synthesis. ${ }^{28}$ One of the more popular reactions that furan rings undergo is the Diels-Alder reaction where furan rings act as the $4 \pi$ diene. Thus, we sought to explore the binding requirements of the KOP receptor through the incorporation of steric bulk into 1 through the utilization of Diels-Alder reactions. Our results are presented below.

\section{RESULTS AND DISCUSSION}

Synthesis. Initially, maleic anhydride and maleimide were reacted with $\mathbf{1}$ in an attempt to form the corresponding adducts, as both dienophiles have been found in the literature to react readily with furan rings. ${ }^{28}$ However, after employing several different solvents (THF, ether, $\mathrm{CH}_{2} \mathrm{Cl}_{2}$, toluene) no reaction with the dienophiles maleic anhydride and maleimide was noted. Several other well-known dienophiles including benzoquinone, dimethyl maleate, dimethyl fumarate, diethyl maleate, diethyl fumarate, methyl vinyl ketone, di-tert-butyl diazo-dicarboxylate, diethyl diazo-dicarboxylate, and dibenzyl diazo dicarboxylate were explored in a variety of reaction conditions. However, none proved successful in generating the desired cycloadducts.

Failure of the cycloaddition reaction to proceed may be attributed to reduced reactivity of the furan ring in $\mathbf{1}$. Although a 1999 publication reported a noncatalyzed Diels - Alder cyclization between maleic anhydride and the furan-containing labdane diterpenoid hedychenone, ${ }^{29}$ a subsequent detailed study ${ }^{30}$ described the necessity for Lewis acid catalysis using $\mathrm{BF}_{3} \cdot \mathrm{OEt}_{2}$ and high temperatures, conditions that we anticipated would surely result in prominent degradation of $1 .{ }^{31}$ Attempts using $\mathrm{AlCl}_{3}$ and $\mathrm{TiCl}_{4}$ to further activate the dienophiles still failed to produce cyclization, with degradation seeming to dominate. One possible explanation for this may be the presence of multiple oxygen moieties in 1 competing for coordination with the Lewis acid, resulting in degradation. It was thought that while $\mathrm{HfCl}_{4}$ is not as reactive as other Lewis acids, ${ }^{32}$ it may be less likely to coordinate with the oxygens of $\mathbf{1}$, thus circumventing the issues seen with $\mathrm{AlCl}_{3}$; however, $\mathrm{HfCl}_{4}$ also failed to catalyze cycloadduct formation. The reason that $\mathbf{1}$ failed to cyclize under the Lewis acid catalyzed conditions required to induce cyclization in hedychenone could
Scheme $1^{a}$

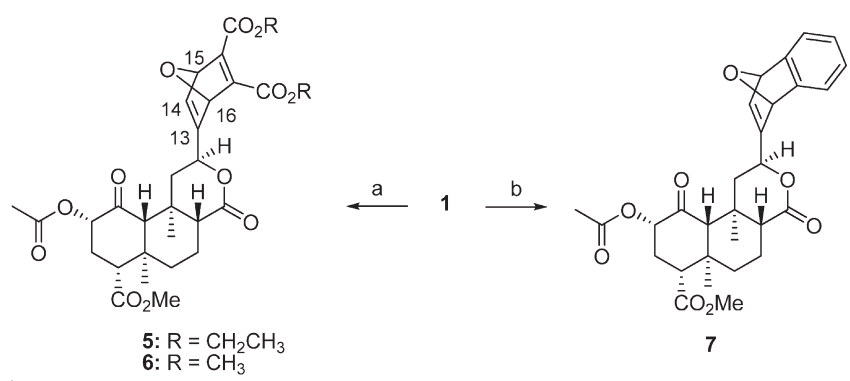

${ }^{a}$ Reagents and conditions: (a) Appropriate alkyne, toluene, reflux; (b) 2-(trimethylsilyl)phenyl trifluoromethane sulfonate, $\mathrm{CsF}, \mathrm{CH}_{3} \mathrm{CN}$, room temperature.

very well be due to the considerable difference in oxygen functionality between these highly structurally dissimilar secondary metabolites.

With the failure of the alkene-type dienophiles, alkynes were explored, as they have been reported to successfully form cycloadducts with furan rings. ${ }^{33}$ Additionally, an advantage to using alkynes in the Diels-Alder reaction is the inability to form additional stereoisomers with respect to the substituents on the existing dienophile (exo vs endo). The reaction of diethyl acetylenedicarboxylate with $\mathbf{1}$ at reflux over the course of two days produced cycloadduct $\mathbf{5}$ as the major product (Scheme 1). While Diels-Alder reactions have been employed for the total synthesis of neoclerodane diterpenes, to our knowledge, this is the first example of a neoclerodane diterpene undergoing chemical modification via the Diels-Alder reaction.

Investigation of the NMR spectra illustrated that the ${ }^{1} \mathrm{H}$ proton signals, which correspond to $\mathrm{C}-15\left(\mathrm{dd}\right.$ at $\left.\delta_{\mathrm{H}} 7.39\right)$ and $\mathrm{H}-16$ (multiplet at $\left.\delta_{\mathrm{H}} 7.41\right)$ and ${ }^{13} \mathrm{C}$ signals for $\mathrm{C}-15\left(\delta_{\mathrm{C}} 143.7\right)$ and $\mathrm{C}-16\left(\delta_{\mathrm{C}} 139.4\right)$ of 1 , were no longer present in cycloadduct 5 (Scheme 1). Signals for the ethoxy groups were readily apparent from the six-proton multiplet at $\delta_{\mathrm{H}} 1.32$ and four-proton multiplet at $\delta_{\mathrm{H}}$ 4.28. Additionally, two new signals representing bridgehead protons were found at $\delta_{\mathrm{H}} 5.66(\mathrm{dd})$ and 5.60 (doublet) along with their corresponding ${ }^{13} \mathrm{C}$ shifts at $\delta_{\mathrm{C}}$ 85.55 and 85.46 . The remaining signals in the ${ }^{13} \mathrm{C}$ spectra were found to be indicative of two carbonyls and four $\mathrm{sp}^{2}$ carbons, which fit the expected shifts of the newly introduced $\alpha, \beta$ unsaturated esters via the Diels-Alder mechanism. These data are consistent with formation of a new oxanorbornadiene ring system in $\mathbf{5}$. The regiochemistry of the oxygen bridge is dependent on the facial orientation between the alkyne and the furan ring of $\mathbf{1}$ (Figure 1). The production of diastereomers is possible, and while HPLC analysis shows a single peak, we are unable to determine the relative configuration at this time. However, additional efforts toward this goal are underway and will be reported in due course.

When reacted under similar conditions, dimethyl acetylene dicarboxylate and $\mathbf{1}$ also successfully form cycloadduct $\mathbf{6}$. There remained a caveat with the formation of cycloadducts 5 and $\mathbf{6}$, specifically that prolonged exposure to heat would cause the cycloadduct to undergo the retro Diels-Alder reaction. This was proven by heating the pure compound 5 in fresh toluene, which yielded a distribution of $\mathbf{5}$ and $\mathbf{1}$ upon isolation. Interestingly, retro Diels-Alder reactions did not result in the salvinorinalkyne and 3,4-substituted furan ring, as might have been predicted; rather, the retro [4+2] resulted in a return of 1 and 

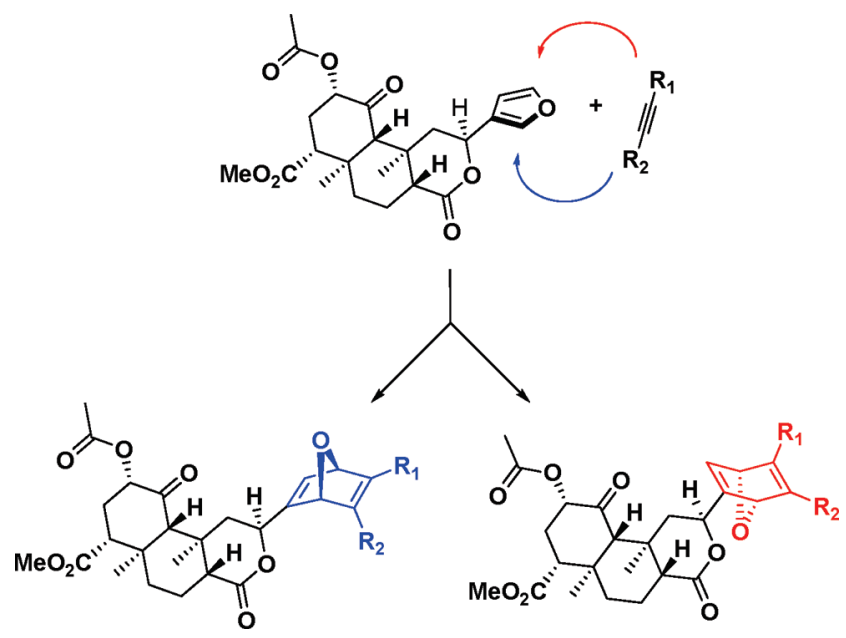

Figure 1. Formation of oxanorbornadiene analogues.

Table 1. Microwave Reaction Conditions for the Synthesis of Cycloadducts 5 and 6

$\begin{array}{llrlll}\text { time }(\mathrm{min}) & \text { absorbance } & \text { temp }\left({ }^{\circ} \mathrm{C}\right) & \text { solvent } & \text { product } & \text { yield \% } \\ 30 & \text { normal } & 50 & \text { dioxane } & \mathbf{5} \text { or } \mathbf{6} & 21 \\ 60 & \text { normal } & 50 & \text { dioxane } & \mathbf{5} \text { or } \mathbf{6} & 23 \\ 30 & \text { low } & 100 & \text { dioxane } & \mathbf{5} \text { or } \mathbf{6} & 62 \\ 60 & \text { low } & 100 & \text { dioxane } & \mathbf{5} \text { or } \mathbf{6} & 64 \\ 30 & \text { normal } & 100 & \text { dioxane } & \mathbf{5} \text { or } \mathbf{6} & 70 \\ 60 & \text { normal } & 100 & \text { dioxane } & \mathbf{5} \text { or } \mathbf{6} & 70 \\ 30 & \text { normal } & 50 & \text { toluene } & \mathbf{5} \text { or } \mathbf{6} & 24 / 15 \\ 60 & \text { normal } & 50 & \text { toluene } & \mathbf{5} \text { or } \mathbf{6} & 30 \\ 30 & \text { low } & 100 & \text { toluene } & \mathbf{5} \text { or } \mathbf{6} & 55 \\ 60 & \text { low } & 100 & \text { toluene } & \mathbf{5} \text { or } \mathbf{6} & 55 \\ 30 & \text { normal } & 100 & \text { toluene } & \mathbf{5} \text { or } \mathbf{6} & 67 \\ 60 & \text { normal } & 100 & \text { toluene } & \mathbf{5} \text { or } \mathbf{6} & 67\end{array}$

the starting alkyne. With the prolonged times needed for cycloadduct formation to occur, it was thought that this phenomenon may be affecting overall yields. In an effort to avoid this retro reaction and to optimize Diels - Alder reactions with $\mathbf{1}$ and alkynes, microwave irradiation was utilized. Several solvents were screened for reaction in the microwave based on their ability to solubilize reagents and polarity, including toluene, xylene, benzene, and dioxane. While various times and absorbance levels were explored, optimal conditions were found to involve either the use of dry and degassed toluene or dioxane at $100{ }^{\circ} \mathrm{C}$ for $30 \mathrm{~min}$ (Table 1).

With optimal microwave conditions found, several other alkynes were reacted with $\mathbf{1}$ in an attempt to form cycloadducts including methyl propiolate, methyl 2-butynoate, methyl phenyl propiolate, and acetylene dicarboxylate. Additionally, the alkenetype dienophiles (maleic anhydride, maleimide, diazo dicarboxylates, benzoquinone, dimethyl maleate, dimethyl fumarate, diethyl maleate, diethyl fumarate) were reacted with 1 under the defined microwave conditions; unfortunately, no cycloadducts incorporating the desired moieties were observed. Failure of the alkynes to form cycloadducts may be due to the presence of only one electron-withdrawing group. Diethyl and dimethyl acetylenedicarboxylate have their sp carbons flanked by electronwithdrawing groups, making the alkyne dienophile increasingly electron poor, which may contribute to its ability to overcome
Scheme $2^{a}$
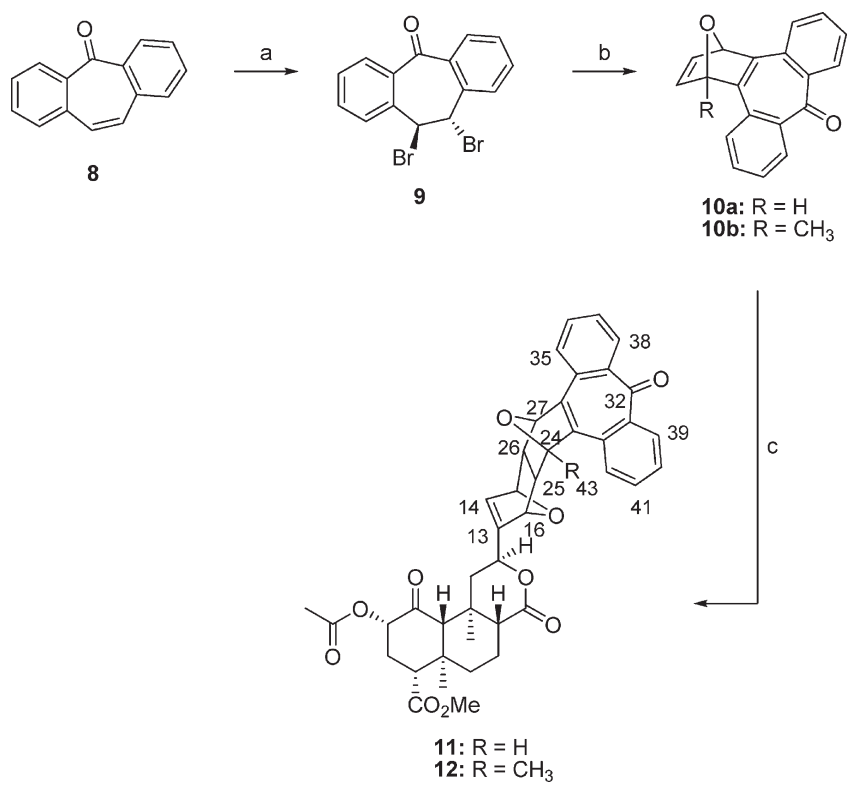

${ }^{a}$ Reagents and conditions: (a) $\mathrm{Br}_{2}, \mathrm{CH}_{2} \mathrm{Cl}_{2}$; (b) $\mathrm{KO}$ - $\mathrm{Bu}$, THF, furan or 2-methyl furan; (c) 1, toluene, reflux.

the reduced activity of the furan ring of $\mathbf{1}$, allowing cycloadduct formation to occur.

To further explore the reactivity of the furan ring in $\mathbf{1}$, its reaction with benzyne was investigated. There are several studies that have demonstrated that benzyne can be effectively trapped by furan rings to form the corresponding cycloadduct. ${ }^{34-36}$ Initial attempts to form the benzyne in situ using anthranilic acid and isoamyl nitrite and trap it with the furan of $\mathbf{1}$ were unsuccessful. However, it was found that when 1 was treated with benzyne generated from 2-(trimethylsilyl)phenyl trifluoromethanesulfonate and cesium fluoride in acetonitrile at room temperature, cycloadduct 7 was formed in $24 \%$ overall yield (Scheme 1). ${ }^{35}$ The structure was confirmed through HRESIMS along with NMR experiments including ${ }^{1} \mathrm{H} \mathrm{NMR},{ }^{13} \mathrm{C} \mathrm{NMR}$, and ${ }^{135} \mathrm{DEPT}$. As with compounds 5 and 6 , the relative configuration of the newly formed oxygen bridge in 7 has not been determined.

While the furan of 1 can participate in Diels-Alder reactions, it seems to react optimally only with very reactive/electron-poor dienophiles, which allows for proper orbital overlap. Potentially the linearity of the alkynes is allowing for the required p-orbital overlap to overcome the activation energy required for reaction, whereas the alkenes would be hindered from the proper overlap due to the positioning over the salvinorin core for the favored endo conformation to form. To further investigate this phenomenon, we investigated the reaction of 1 with 3,6-epoxy-3,6dihydrotribenzocycloheptatrienone (10a). ${ }^{37,38}$ Trienone 10a and similar compounds have been shown to readily react in Diels-Alder reaction with furans with the trienone serving as the dienophile (Scheme 2). The added advantage of selecting these compounds is that they exhibit mild blue light-emitting effects and are direct precursors to a recently described class of fluorescent ligands. ${ }^{39}$ In addition to serving as dienophiles that would add steric bulk to 1 , they may also provide new avenues toward fluorescent neoclerodanes, potentially helping elucidate how 1 interacts at opioid receptors. 
The reaction of dibenzosuberenone (8) with $\mathrm{Br}_{2}$ in $\mathrm{CH}_{2} \mathrm{Cl}_{2}$ at $0{ }^{\circ} \mathrm{C}$ yielded the dibromo intermediate (9), which was treated with $\mathrm{KO} t-\mathrm{Bu}$ and either furan or 2-methylfuran in THF to produce compounds 10a and $10 \mathrm{~b}$ (Scheme 2). Reaction of 1 with 10a under standard reflux conditions yielded cycloadduct 11 as a mixture of C-15/C-16 exo and endo isomers. The suggestion of a mixture of endo and exo isomers was corroborated by the presence of a doubling of signals in both the ${ }^{1} \mathrm{H}$ NMR and ${ }^{13} \mathrm{C}$ NMR spectra as well as the corresponding mass of cycloadduct 11 observed by HRESIMS. While cycloadduct 11 was obtained as a mixture of exo and endo products, cycloadduct $\mathbf{1 2}$ was obtained as a single compound as seen from the lack of signal doubling in the ${ }^{1} \mathrm{H}$ NMR and ${ }^{13} \mathrm{C}$ NMR spectra. HRESIMS analysis corresponded to a molecular formula that matched the predicted formula of $\mathbf{1 2}$.

To determine the location of the methyl group and if the cycloadduct was endo or exo regarding its orientation, extensive NMR experiments were conducted. The first step was to determine whether C-43 was proximal or distal (cis or trans) to the core of 1 . HMBC experiments were able to show ${ }^{1} \mathrm{H}$ and ${ }^{13} \mathrm{C}$ couplings to trace the carbon framework of 12, showing that C-43 is in fact proximal or cis to the salvinorin core (Figure S4). This also helped to establish the carbon framework of 12, which was found to be in agreement with the proposed product of the Diels-Alder reaction. With regard to the assignment of endo or exo configuration, it was anticipated that steric effects would force cycloaddition to occur through an endo,exo approach. As described previously, ${ }^{40}$ an endo,exo approach eliminates unfavorable steric interactions between dienophile and diene, resulting in formation of a single product. This would cause $10 \mathrm{~b}$ to

Scheme $3^{a}$

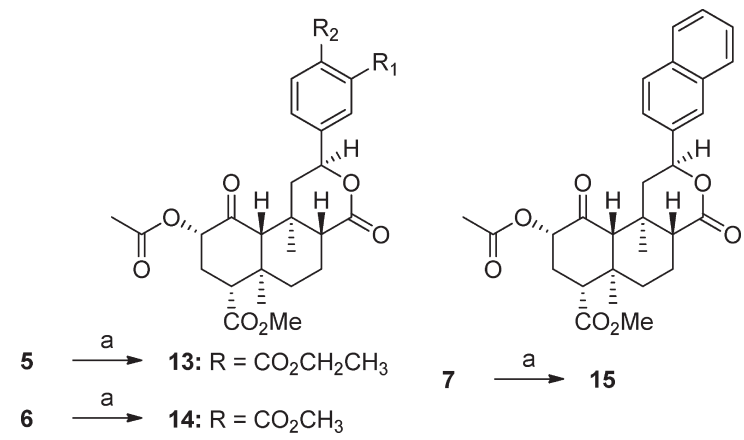

${ }^{a}$ Reagents and conditions: (a) $\mathrm{Fe}_{2}(\mathrm{CO})_{9}$, toluene, reflux. approach from the face of the furan opposite the tricyclic core of $\mathbf{1}$, as depicted by the red arrow in Figure 1, causing the methyl group to be oriented as shown in Scheme 2. Although we were unable to verify this with a crystal structure, analysis of the ${ }^{3} J_{\mathrm{H}, \mathrm{H}}$ coupling values (for details, see the Supporting Information) seen in the ${ }^{1} \mathrm{H}$ NMR spectrum of 12 supports the hypothesis that the final product exhibits an endo,exo configuration. The results seen with the reactions of $10 \mathrm{a}$ and $10 \mathrm{~b}$ with 1 appear to be in agreement with those described previously, ${ }^{40}$ wherein the inclusion of alkyl substituents at the bridgehead carbons caused a shift in endo/exo preference (as seen in 12), with nonsubstituted reagents showing no selectivity (as seen in 11).

The synthesis of cycloadducts 5-7 not only provided analogues that introduced steric bulk at the furan position of $\mathbf{1}$, but also provided useful synthetic intermediates. Treatment of compound 5 with $\mathrm{Fe}_{2}(\mathrm{CO})_{9}$ caused a reductive elimination of water and consequent aromatization to produce compound $\mathbf{1 3}$ (Scheme 3). ${ }^{41}$ Analysis of HRESIMS data verified the expected mass of the new compound, and examination of ${ }^{1} \mathrm{H}$ and ${ }^{13} \mathrm{C}$ spectra verified that the oxygen bridge present in $\mathbf{5}$ was indeed absent. Furthermore, new aromatic signals were observed in both the ${ }^{1} \mathrm{H}$ and ${ }^{13} \mathrm{C}$ spectra that were in good agreement with the proposed new structure. This reaction also proved successful in transforming compounds 6 and 7 to their corresponding aromatic rings at the $\mathrm{C}-12$ position, 14 and 15 , respectively. These compounds are significant from a synthetic standpoint, as they are the first reported examples of non-heterocyclic aromatic rings directly attached to the core of neoclerodane diterpenes.

Finally, we sought to explore the reactivity of the furan ring with a nonsymmetrical alkyne. The reaction of ethyl 4,4,4-trifluoro2-butynoate with 1 at $95{ }^{\circ} \mathrm{C}$ gave a mixture of $16 \mathrm{a}$ and $16 \mathbf{b}$ (Scheme 4) in a 91:9 ratio, as determined by analytical HPLC. While our initial predictions assumed a mixture of regioisomers would form, this hypothesis was realized upon careful examination of multiple NMR spectra, including HSQC, DEPT135, and COSY NMR. Particularly, there was a doubling of signals realized for the $\mathrm{sp}^{2}$-hybridized methine at $\mathrm{C}$-14, which appeared as a doublet of doublets instead of an anticipated doublet. These signals were coupled with two carbon signals at $\delta_{\mathrm{C}} 84.42$ and 85.01, which corresponds to the western bridgehead carbon (C-15). Additionally, simultaneous ${ }^{3} \mathrm{~J}_{\mathrm{CF}}$ coupling was seen with both bridgehead carbons $\mathrm{C}-15$ and $\mathrm{C}-16$ in the fluorine-coupled carbon spectrum, which suggests that the $\mathrm{CF}_{3}$ group was attached to both C-26 and C-27 at the same time. This could be explained by the sample containing a mixture of regioisomers $16 \mathrm{a}$ and $\mathbf{1 6 b}$. Our attempts to separate $16 \mathrm{a}$ and $\mathbf{1 6 b}$ on a preparative scale

\section{Scheme $4^{a}$}

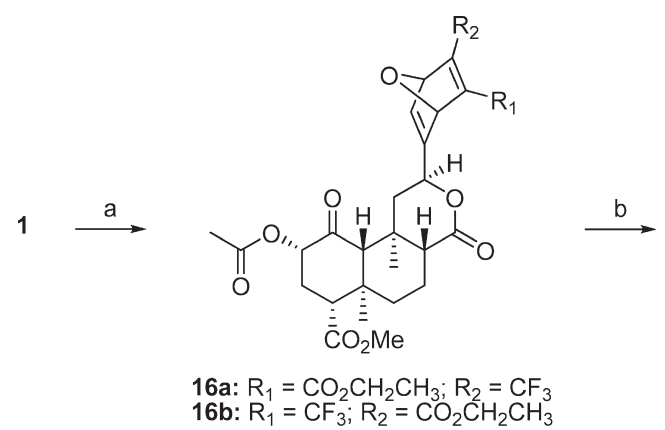

16a: $\mathrm{R}_{1}=\mathrm{CO}_{2} \mathrm{CH}_{2} \mathrm{CH}_{3} ; \mathrm{R}_{2}=\mathrm{CF}_{3}$
16b: $\mathrm{R}_{1}=\mathrm{CF}_{3} ; \mathrm{R}_{2}=\mathrm{CO}_{2} \mathrm{CH}_{2} \mathrm{CH}_{3}$

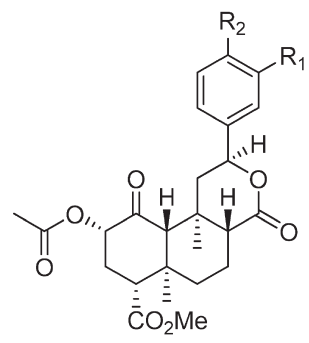

17a: $\mathrm{R}_{1}=\mathrm{CO}_{2} \mathrm{CH}_{2} \mathrm{CH}_{3} ; \mathrm{R}_{2}=\mathrm{CF}_{3}$
17b: $\mathrm{R}_{1}=\mathrm{CF}_{3} ; \mathrm{R}_{2}=\mathrm{CO}_{2} \mathrm{CH}_{2} \mathrm{CH}_{3}$

\footnotetext{
${ }^{a}$ Reagents and conditions: (a) ethyl 4,4,4-trifluoro-2-butynoate, toluene, reflux; (b) $\mathrm{Fe}_{2}(\mathrm{CO})_{9}$, toluene, reflux.
} 
using column chromatography under various solvent conditions were unsuccessful, meaning that the unambiguous determination of $16 \mathrm{a}$ and $16 \mathrm{~b}$ was not possible. The preference to form cycloadduct $16 \mathrm{a}$ over $16 \mathrm{~b}$ can potentially be explained by the difference in electron-withdrawing groups that flank the alkyne. We propose that the stronger electron-withdrawing $\mathrm{CF}_{3}$ group promotes a more electron-rich end to the alkyne that pairs to $\mathrm{C}-15$ due to the inductive push of electron density to C-16 from the core of 1 .

Given our success with converting oxanorbornadienes to the corresponding phenyl rings, we decided to convert the mixture of $16 \mathrm{a}$ and $16 \mathrm{~b}$ to their corresponding phenyl derivatives. It was envisioned that a mixture of the phenyl derivatives would be more easily separated than the mixture of oxanorbornadienes. As expected, the treatment of the mixture of $16 \mathrm{a}$ and $16 \mathrm{~b}$ with $\mathrm{Fe}_{2}(\mathrm{CO})_{9}$ in toluene gave the corresponding phenyl rings. To our delight, $\mathbf{1 7} \mathbf{a}$ and $\mathbf{1 7 b}$ (Scheme 4) were isolated in $62 \%$ and $4 \%$ yield, respectively. The structure of $17 \mathrm{a}$ was elucidated in a fashion similar to $\mathbf{1 6 a}$ and $\mathbf{1 6 b}$ by first identifying the three aromatic protons at $\delta 7.72,7.69$, and 7.50 , which all correlate to aromatic carbons in the HSQC. Additionally the two protons at $\delta$ 7.72 and 7.50 are correlated to each other in the COSY spectrum, which would represent C-14 and C-15 (Figure 2). Further analysis of the COSY spectrum showed that the proton signal at $\delta 7.69$ was not correlated to any other protons, indicating that it was attached to the $\mathrm{C}-16$ position. Examination of the $\mathrm{HMBC}$

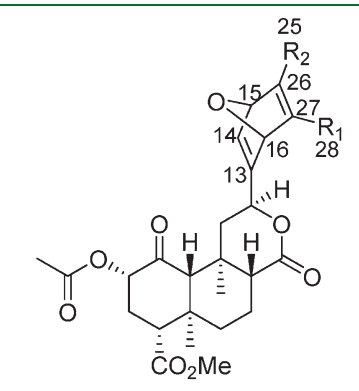

16a: $\mathrm{R}^{1}=\mathrm{CO}_{2} \mathrm{CH}_{2} \mathrm{CH}_{3}, \mathrm{R}^{2}=\mathrm{CF}_{3}$ 16b: $\mathrm{R}^{1}=\mathrm{CF}_{3}, \mathrm{R}^{2}=\mathrm{CO}_{2} \mathrm{CH}_{2} \mathrm{CH}_{3}$

Figure 2. Partial numbering of compounds 16a, 16b, and 17a with selected HMBC correlations. spectrum showed that the proton signal at $\delta 7.72$ was correlated to $\mathrm{C}-25, \mathrm{C}-27$, and $\mathrm{C}-13$, while the proton signal at $\delta 7.69$ was correlated to $\mathrm{C}-28, \mathrm{C}-26$, and $\mathrm{C}-12$. This would suggest that the COSY uncoupled proton signal from $\delta 7.69$ is attached to C-16 and the COSY coupled proton signal from $\delta 7.72$ is attached to $\mathrm{C}-15$. The structure of $\mathbf{1 7 b}$ was elucidated in a similar manner to 17a. The success of our methodology suggests that this approach may be applicable to other furan ring containing natural products in efforts to rapidly explore their SAR.

Biological Results. The synthesized compounds were evaluated for affinity and efficacy at opioid receptors. ${ }^{42}$ It was the thought that the cycloadducts prepared would give greater insight into the position of the oxygen atom and its ability to participate in hydrogen bonding. Additionally, these compounds would provide some measure of the amount of steric bulk that was tolerated around the furan ring. Cycloadduct 6 had decreased but still appreciable affinity for KOP receptors in comparison to $1\left(K_{\mathrm{i}}=60 \mathrm{nM}\right.$ vs $\left.K_{\mathrm{i}}=7.4 \mathrm{nM}\right)$ (Table 2). The diethyl analogue $6(5)$ saw a decrease in affinity at KOP receptors when compared to its methyl counterpart, $6\left(K_{\mathrm{i}}=120 \mathrm{nM}\right.$ vs $K_{\mathrm{i}}=$ $60 \mathrm{nM})$. While affinity for KOP receptors was diminished in $\mathbf{5}$, affinity for delta opioid (DOP) receptors increased over 4-fold in comparison to $1\left(K_{\mathrm{i}}=2,260 \mathrm{nM}\right.$ vs $\left.K_{\mathrm{i}}>10000 \mathrm{nM}\right)$. As mentioned above, we were unable to assign the relative configuration of the oxygen of the oxanorbornadiene in $\mathbf{5}$ and $\mathbf{6}$. It is therefore possible that one regioisomer of the oxanorbornadiene is preferred for interacting with opioid receptors. However, additional synthesis and biological testing will be required to test this hypothesis.

Cycloadduct 7 also explored the role of steric bulk in activity at opioid receptors along with increasing the lipophilic/hydrophobic characteristics of 1 through the introduction of a benzene ring instead of esters, allowing us to investigate how these characteristics factor into activity at opioid receptors. Cycloadduct 7 was found to have decreased affinity at KOP receptors $\left(K_{\mathrm{i}}=790 \mathrm{nM}\right)$ in comparison to $\mathbf{1}$. This decreased affinity may be the result of 7 not having the ability to form hydrogen bonds like its estercontaining cycloadduct counterparts and/or the regiochemistry of the oxanorbornadiene is not optimal. The installation of substituents that may partake in hydrogen bonding on the benzene ring of 7 may improve affinity at opioid receptors and warrants further investigation.

Table 2. Binding Affinities of Cycloadduct Analogues ${ }^{a}$

\begin{tabular}{|c|c|c|c|c|c|}
\hline \multirow[b]{2}{*}{ compound } & \multicolumn{3}{|c|}{$K_{\mathbf{i}} \pm \mathrm{SD}(\mathrm{nM})$} & \multirow[b]{2}{*}{$\mathrm{MOP} / \mathrm{KOP}$} & \multirow[b]{2}{*}{$\mathrm{DOP} / \mathrm{KOP}$} \\
\hline & MOP & DOP & KOP & & \\
\hline \multirow[t]{2}{*}{1} & $\mathrm{EC}_{50}=2860 \pm 980^{b}$ & $>10000$ & $7.4 \pm 0.7$ & N.D. ${ }^{c}$ & $>1351$ \\
\hline & $E_{\max }=75 \pm 8 \%$ & & & & \\
\hline 5 & $>3200$ & $2260 \pm 280$ & $120 \pm 10$ & $>25$ & 19 \\
\hline 6 & $>4800$ & $>5000$ & $60 \pm 10$ & $>80$ & $>83$ \\
\hline 7 & $>2500$ & $>10000$ & $790 \pm 200$ & $>3$ & $>13$ \\
\hline 11 & $>2700$ & $>5200$ & $>13000$ & $>0.2$ & $>17$ \\
\hline 12 & $>1700$ & $>5000$ & $290 \pm 20$ & $>6$ & $>17$ \\
\hline 13 & $>3000$ & $>5000$ & $228 \pm 12$ & $>13$ & $>22$ \\
\hline 14 & $>3000$ & $>5000$ & $286 \pm 19$ & $>8$ & $>17$ \\
\hline 15 & $>3000$ & $>5000$ & $>8000$ & $>0.4$ & $>0.6$ \\
\hline $16 a / 16 b$ & $1670 \pm 150$ & $>5000$ & $1970 \pm 80$ & 0.85 & $>2$ \\
\hline
\end{tabular}

${ }^{a}\left[{ }^{3} \mathrm{H}\right]$ DAMGO was used for MOP, $\left[{ }^{3} \mathrm{H}\right]$ DADLE for DOP, and $\left[{ }^{3} \mathrm{H}\right] \mathrm{U} 69,593$ for KOP receptors. ${ }^{b}$ A more complete analysis provided this value, which corrects our previously reported value. ${ }^{12}{ }^{c}$ Not determined. 
Table 3. $\left[{ }^{35}\right.$ S $]$ GTP- $\gamma$-S Activity Assay of Cycloadducts

$\begin{array}{lcc}\text { compound } & \mathrm{KOP}_{\mathrm{ED}}{ }^{a} \pm \mathrm{SD}, \mathrm{nM} & \mathrm{KOP}_{\max }{ }^{b} \pm \mathrm{SD}, \mathrm{nM} \\ \mathbf{1} & 40 \pm 10 & 120 \pm 2 \\ \mathbf{5} & 2150 \pm 500 & 90 \pm 10 \\ \mathbf{6} & 980 \pm 200 & 100 \pm 10 \\ { }^{a} \mathrm{ED}_{50}=\text { effective dose for } 50 \% \text { maximal response. }{ }^{b} E_{\max } \text { is \% at which } \\ \text { compound stimulates in comparison to (-)-U50,488 (500 nM) at KOP } \\ \text { receptors. }\end{array}$

Further probing how steric bulk affects the interactions of $\mathbf{1}$ at opioid receptors, the incorporation of large appendages to the core structure of 1 resulted in the synthesis of 11 and 12. Given that the core structures of $\mathbf{1 1}$ and $\mathbf{1 2}$ had fluorescent properties, it was the hope that these analogues of $\mathbf{1}$ could be used as potential visualizing agents for opioid receptors, along with exploring the effect of increased steric bulk. Unfortunately, cycloadduct 11 had no affinity at KOP receptors, as it had a $K_{\mathrm{i}}$ of $>13000 \mathrm{nM}$ and no appreciable affinity for mu opioid (MOP) or DOP receptors as well. Interestingly, the introduction of a methyl group into the bridgehead of 11 (12) increased affinity for KOP receptors 44fold $\left(K_{\mathrm{i}}=290 \mathrm{nM}\right.$ vs $\left.K_{\mathrm{i}}>13000 \mathrm{nM}\right)$. The rationale behind this observed result is not immediately apparent but may be attributed to 11 being tested as a mixture of endo and exo isomers, while $\mathbf{1 2}$ was tested as a single isomer. Further studies are being explored to evaluate this hypothesis.

The phenyl ring analogues were also evaluated to explore steric bulk and the effects of non-heterocyclic aromatics at the C-12 position. The napthyl derivative of $7(\mathbf{1 5})$ had no affinity at opioid receptors $\left(K_{\mathrm{i}}>10000 \mathrm{nM}\right)$, indicating that the lack of any groups that may hydrogen bond is detrimental for affinity at opioid receptors. This possible explanation seems to be corroborated by phenyl derivatives of 5 (13) and 6 (14), as they retained some affinity for KOP receptors though less than 1 (14: $K_{\mathrm{i}}=228 \mathrm{nM} ; 15: K_{\mathrm{i}}=286 \mathrm{nM}$ vs $\left.K_{\mathrm{i}}=7.4 \mathrm{nM}\right)$.

Along with the bridgehead oxygen, it was thought that the carbonyls of the additional esters might be hydrogen bonding at opioid receptors. Investigation of this hypothesis was possible with 16, where one of the ethyl esters of 5 was replaced with a $\mathrm{CF}_{3}$ group. Introduction of the $\mathrm{CF}_{3}$ group led to a 16-fold decrease in affinity at KOP receptors in comparison to $5\left(K_{\mathrm{i}}=\right.$ $1970 \mathrm{nM}$ vs $120 \mathrm{nM}$ ). This suggested that an additional carbonyl in this position assists in binding; however, a clear explanation has yet to be determined, which is in part due to 16 being tested as a mixture of regioisomers. Evaluation of each individual regioisomer will be necessary to further investigate the impact of the carbonyl moiety as well as the position of the $\mathrm{CF}_{3}$. This will aid in the investigation of our initial hypothesis pertaining to the hydrogen-bonding capabilities of the esters and their role in binding at opioid receptors.

With cycloadducts 5 and $\mathbf{6}$ having relatively high affinity for KOP receptors $\left(K_{\mathrm{i}} \leq 150 \mathrm{nM}\right)$, they were evaluated for efficacy at opioid receptors in the $\left.{ }^{35} \mathrm{~S}\right] \mathrm{GTP}-\gamma-\mathrm{S}$ assay. Cycloadduct 6 was found to be a full agonist at KOP receptors compared to $(-)$ U50,488 $\left(E_{\max }=100 \pm 10\right)$ (Table 3). Cycloadduct 5 was also found to have high efficacy in this assay $\left(E_{\max }=90\right)$; however both compounds were less potent than $1\left(6 \mathrm{ED}_{50}=980 \mathrm{nM}\right.$ vs $5 \mathrm{ED}_{50}=$ $\left.2150 \mathrm{vs} \mathrm{ED}_{50}=40 \mathrm{nM}\right)$. These compounds show that extension of the cycloadduct esters has more of an effect on potency than overall efficacy, and both compounds further illustrate that the furan ring 1 of is not essential for binding or efficacy at opioid receptors and some steric bulk is tolerated at this position.
In conclusion, a series of Diels - Alder cycloadduct analogues of salvinorin A were synthesized in an effort to explore the effects of steric bulk and the position of the oxygen ring on binding and activity at opioid receptors. Microwave conditions were optimized to further enhance the amenability of the furan ring in salvinorin A to serve as a $4 \pi$ diene in the [4+2] Diels-Alder reaction. This work signifies the first reported example of the Diels-Alder reaction to modify a neoclerodane diterpene. Furthermore, several of the cycloadduct analogues were themselves useful as synthetic intermediates, as they were able to undergo reductive elimination to produce their phenyl ring counterparts. In vitro evaluation found that steric bulk around the furan ring of salvinorin A seems to be tolerated for binding at the KOP receptor, as cycloadducts 5, 6, and $\mathbf{1 2}$ maintained appreciable affinity. Although all compounds explored had reduced affinity relative to salvinorin $\mathrm{A}$, this indicates that the furan ring is not a stringent requirement for KOP receptor affinity, as previously believed. Additionally, cycloadducts 5 and $\mathbf{6}$ were found to be full agonists at KOP receptors as compared to the known KOP agonist U50,488. Furthermore, phenyl derivatives 13 and 14 maintained modest affinity at KOP receptors, which further indicates that the furan ring is not essential for affinity at opioid receptors. Further investigation into the role of steric bulk at the furan ring will yield valuable information into the nature of how $\mathbf{1}$ interacts at opioid receptors. This information can then be used to aid in the development of opioid therapeutics with enhanced pharmacological properties.

\section{EXPERIMENTAL SECTION}

General Experimental Procedures. Unless otherwise indicated, all reagents were purchased from commercial suppliers and were used without further purification. Melting points were determined on a Thomas-Hoover capillary melting apparatus. NMR spectra were recorded on either a Bruker Advance-300 spectrometer, a Bruker DRX400 with qnp probe, or a Bruker AV-500 with cryoprobe using $\delta$ values in ppm (TMS as internal standard) and $J(\mathrm{~Hz})$ assignments of ${ }^{1} \mathrm{H}$ resonance coupling. High-resolution mass spectrometry data were collected on either a LCT Premier (Waters Corp.) time-of-flight mass spectrometer or an Agilent $6890 \mathrm{~N}$ gas chromatograph in conjunction with a Quattro Micro GC mass spectrometer (Micromass Ltd.). Thin-layer chromatography (TLC) was performed on $0.25 \mathrm{~mm}$ Analtech GHLF silica gel plates using EtOAc/ $n$-hexanes, in 1:1 ratio, as the solvent system unless otherwise noted. Spots on TLC were visualized by UV ( 254 or $365 \mathrm{~nm}$ ), phosphomolybdic acid in EtOH, or vanillin $/ \mathrm{H}_{2} \mathrm{SO}_{4}$ in EtOH. Column chromatography was performed with silica gel $(32-63 \mu \mathrm{m}$ particle size) from MP Biomedicals. Analytical HPLC was carried out on an Agilent 1100 Series Capillary HPLC system with diode array detection at $254.8 \mathrm{~nm}$ on an Agilent Eclipse XDB-C18 column $(4.6 \times 150 \mathrm{~mm}, 5 \mathrm{~mm})$ with isocratic elution in $60 \% \mathrm{CH}_{3} \mathrm{CN} / 40 \% \mathrm{H}_{2} \mathrm{O}$ at a flow rate of $5.0 \mathrm{~mL} / \mathrm{min}$ unless otherwise noted. The systematic name for salvinorin A $(\mathbf{1})$ is $(2 S, 4 \mathrm{a} R, 6 \mathrm{a} R, 7 R, 9 S, 10 \mathrm{aS}, 10 \mathrm{~b} R)$-methyl 9-acetoxy-2-(furan-3-yl)-6a,10bdimethyl-4,10-dioxododecahydro- $1 H$-benzo $[f]$ isochromene-7-carboxylate. Salvinorin A was isolated from $S$. divinorum as previously described. ${ }^{43}$

Diethyl 5-((2S,4aR,6aR,7R,9S,10aS,10bR)-9-acetoxy-7-(methoxycarbonyl)-6a,10b-dimethyl-4,10-dioxododecahydro1 H-benzo[f] isochromen-2-yl)-7-oxabicyclo[2.2.1] hepta-2, 5-diene-2,3-dicarboxylate (5). A solution of 1 (200 mg, 0.462 $\mathrm{mmol})$, diethyl acetylene dicarboxylate $(85 \mathrm{mg}, 0.500 \mathrm{mmol})$, and toluene $(20 \mathrm{~mL})$ was allowed to stir at room temperature and gradually heated to reflux over $45 \mathrm{~min}$. The solution was heated at reflux for two days. The solvent was removed under reduced pressure, and the resulting residue was purified by column chromatography 
(eluent: EtOAc/n-hexanes, $2: 3)$ to afford $262 \mathrm{mg}$ of $5(70 \%)$ as a white powder: $\mathrm{mp} 84-86{ }^{\circ} \mathrm{C} ;{ }^{1} \mathrm{H}$ NMR $\left(500 \mathrm{MHz}, \mathrm{CDCl}_{3}\right) \delta 6.92$ $(1 \mathrm{H}, \mathrm{ddd}, J=1.9,3.6 \mathrm{~Hz}), 5.66(1 \mathrm{H}, \mathrm{t}, J=1.8 \mathrm{~Hz}), 5.60(1 \mathrm{H}, \mathrm{d}, J=1.6$ $\mathrm{Hz}), 5.39(1 \mathrm{H}, \mathrm{dd}, J=3.8,11.7 \mathrm{~Hz}), 5.29(1 \mathrm{H}, \mathrm{d}, J=7.7 \mathrm{~Hz}), 5.22-$ $5.08(2 \mathrm{H}, \mathrm{m}), 4.33-4.23(4 \mathrm{H}, \mathrm{m}), 3.73(3 \mathrm{H}, \mathrm{s}), 2.78-2.72(1 \mathrm{H}, \mathrm{m})$, $2.43(1 \mathrm{H}, \mathrm{d}, J=5.6 \mathrm{~Hz}), 2.41(1 \mathrm{H}, \mathrm{d}, J=5.5 \mathrm{~Hz}), 2.31(2 \mathrm{H}, \mathrm{dd}, J=3.2$, $11.0 \mathrm{~Hz}), 2.17(4 \mathrm{H}, \mathrm{d}, J=3.1 \mathrm{~Hz}), 1.80-1.75(1 \mathrm{H}, \mathrm{m}), 1.50(2 \mathrm{H}, \mathrm{dd}$, $J=11.3,23.9 \mathrm{~Hz}), 1.40(3 \mathrm{H}, \mathrm{d}, J=1.6 \mathrm{~Hz}), 1.32(6 \mathrm{H}, \mathrm{ddd}, J=2.8,6.3$, $10.1 \mathrm{~Hz}), 1.10(3 \mathrm{H}, \mathrm{s}) ;{ }^{13} \mathrm{C}$ NMR $\left(126 \mathrm{MHz}, \mathrm{CDCl}_{3}\right) \delta 202.0,171.6$, 170.7, 169.9, 163.1, 157.8, 152.8, 151.9, 138.0, 136.4, 85.6, 85.3, 74.9, 73.9, $64.1,61.8,61.6,53.5,52.0,51.2,42.0,41.2,40.3,38.0,35.4,30.8,20.6,18.1$, 16.3, 15.3, 14.1; HRESIMS $m / z 625.2203[\mathrm{M}+\mathrm{Na}]$ (calcd for $\mathrm{C}_{31} \mathrm{H}_{38^{-}}$ $\left.\mathrm{O}_{12} \mathrm{Na}, 625.2261\right)$; HPLC $t_{\mathrm{R}}=6.802 \mathrm{~min}$; purity $=96 \%$.

Dimethyl 5-((2S,4aR,6aR,7R,9S,10aS,10bR)-9-acetoxy-7-(methoxycarbonyl)-6a,10b-dimethyl-4,10-dioxododecahydro$1 \mathrm{H}$-benzo[f]isochromen-2-yl)-7-oxabicyclo[2.2.1] hepta-2, 5-diene-2,3-dicarboxylate (6). Method A. Compound 6 was prepared from 1 and dimethyl acetylene dicarboxylate using a similar procedure to that for 5 to afford $152 \mathrm{mg}(70 \%)$ as a white solid.

Method B. A solution of 1 (100 mg, $0.23 \mathrm{mmol})$, dimethyl acetylene dicarboxylate $(35 \mathrm{mg}, 0.25 \mathrm{mmol})$, and toluene $(25 \mathrm{~mL})$ was placed in a sealed $25 \mathrm{~mL}$ quartz tube and irradiated in a microwave reactor (Biotage Initiator) at $100{ }^{\circ} \mathrm{C}$ for $30 \mathrm{~min}$ with normal absorbance levels. Solvent was removed under reduced pressure, and the resulting residue was purified using column chromatography (EtOAc $/ n$-hexanes, 2:3) to afford $69 \mathrm{mg}(63 \%)$ as a white solid: $\mathrm{mp} 107-110{ }^{\circ} \mathrm{C} ;{ }^{1} \mathrm{H} \mathrm{NMR}(500 \mathrm{MHz}$, $\left.\mathrm{CDCl}_{3}\right) \delta 6.91(1 \mathrm{H}, \mathrm{d}, J=12.2 \mathrm{~Hz}), 5.71(1 \mathrm{H}, \mathrm{d}, J=1.6 \mathrm{~Hz}), 5.67(1 \mathrm{H}$, s), $5.63(1 \mathrm{H}, \mathrm{d}, J=1.6 \mathrm{~Hz}), 5.40-5.35(1 \mathrm{H}, \mathrm{m}), 5.32-5.26(1 \mathrm{H}, \mathrm{m})$, $3.85(3 \mathrm{H}, \mathrm{s}), 3.82(3 \mathrm{H}, \mathrm{d}, J=1.4 \mathrm{~Hz}), 3.73(3 \mathrm{H}, \mathrm{s}), 2.74(1 \mathrm{H}, \mathrm{s}), 2.42$ $(1 \mathrm{H}, \mathrm{s}), 2.31(2 \mathrm{H}, \mathrm{d}, J=7.4 \mathrm{~Hz}), 2.17(4 \mathrm{H}, \mathrm{d}, J=3.7 \mathrm{~Hz}), 2.05(2 \mathrm{H}, \mathrm{s})$, $1.80-1.75(1 \mathrm{H}, \mathrm{m}), 1.47(2 \mathrm{H}, \mathrm{s}), 1.40(3 \mathrm{H}, \mathrm{s}), 1.10(3 \mathrm{H}, \mathrm{s}) ;{ }^{13} \mathrm{C} \mathrm{NMR}$ $\left(126 \mathrm{MHz}, \mathrm{CDCl}_{3}\right) \delta 200.8,171.5,170.6,170.0,162.8,157.8,137.9$, 136.5, 84.3, 84.2, 84.1, 73.6, 72.5, 71.7, 62.7, 62.7, 52.2, 51.4, 51.2, 50.8, 49.7, 40.7, 39.8, 36.7, 34.1, 19.4, 16.8, 15.1, 14.0; HRESIMS $\mathrm{m} / \mathrm{z}$ $597.1921[\mathrm{M}+\mathrm{Na}]\left(\right.$ calcd for $\mathrm{C}_{29} \mathrm{H}_{34} \mathrm{O}_{12} \mathrm{Na}$, 597.1948); HPLC $t_{\mathrm{R}}=$ $4.757 \mathrm{~min}$; purity $=97 \%$.

$(2 S, 4 \mathrm{a} R, 6 \mathrm{a} R, 7 R, 9 \mathrm{~S}, 10 \mathrm{aS}, 10 \mathrm{~b} R)$-Methyl 9-acetoxy-2-(7-benzooxabicyclo[2.2.1] hepta-2,5-dien-2-yl)-6a,10b-dimethyl-4, 10-dioxododecahydro- $1 H$-benzo[f]isochromene-7-carboxylate (7). To a solution of $\mathbf{1}(150 \mathrm{mg}, 0.35 \mathrm{mmol}), 2$-(trimethylsilyl)phenyl trifluoromethanesulfonate $(310.6 \mathrm{mg}, 1.04 \mathrm{mmol})$, and $\mathrm{CH}_{3} \mathrm{CN}$ $(20 \mathrm{~mL})$ was added CsF $(319 \mathrm{mg}, 2.1 \mathrm{mmol})$, and the solution was allowed to stir at room temperature overnight. Upon completion, the reaction was diluted with $\mathrm{H}_{2} \mathrm{O}(25 \mathrm{~mL})$ and ether $(25 \mathrm{~mL})$. The aqueous layer was extracted with ether and dried $\left(\mathrm{Na}_{2} \mathrm{SO}_{4}\right)$. The compound was purified by column chromatography (eluent: EtOAc/ $n$-hexanes, 1:1) to afford $42.4 \mathrm{mg}$ of 7 (24\%) as a white powder: $\mathrm{mp} 242-245^{\circ} \mathrm{C}$ (dec); ${ }^{1} \mathrm{H}$ NMR $\left(500 \mathrm{MHz}, \mathrm{CDCl}_{3}\right) \delta 7.33-7.31(1 \mathrm{H}, \mathrm{m}), 7.25-7.22(1 \mathrm{H}$, m), $7.01(2 \mathrm{H}, \mathrm{dd}, J=3.0,5.1 \mathrm{~Hz}), 6.69(1 \mathrm{H}, \mathrm{t}, J=2.0 \mathrm{~Hz}), 5.72(2 \mathrm{H}, \mathrm{d}$, $J=11.9 \mathrm{~Hz}), 5.17-5.09(2 \mathrm{H}, \mathrm{m}), 3.72(3 \mathrm{H}, \mathrm{s}), 2.73-2.68(1 \mathrm{H}, \mathrm{m})$, $2.37-2.33(1 \mathrm{H}, \mathrm{m}), 2.31-2.26(2 \mathrm{H}, \mathrm{m}), 2.17(3 \mathrm{H}, \mathrm{s}), 2.11(1 \mathrm{H}, \mathrm{s}), 1.95$ $(1 \mathrm{H}, \mathrm{d}, J=11.9 \mathrm{~Hz}), 1.76(1 \mathrm{H}, \mathrm{d}, J=13.4 \mathrm{~Hz}), 1.66-1.58(1 \mathrm{H}, \mathrm{m})$, $1.53-1.45(2 \mathrm{H}, \mathrm{m}), 1.37(3 \mathrm{H}, \mathrm{s}), 1.31(1 \mathrm{H}, \mathrm{s}), 1.07(3 \mathrm{H}, \mathrm{s}) ;{ }^{13} \mathrm{C} \mathrm{NMR}$ $\left(126 \mathrm{MHz} \mathrm{CDCl}_{3}\right) \delta 199.7,169.1,168.5,167.6,153.9,146.2,145.7$, 134.1, 123.1, 122.9, 118.3, 117.8, 80.5, 79.8, 72.7, 71.4, 61.8, 51.1, 49.6, 48.5, 39.8, 37.6, 35.6, 32.8, 28.3, 18.2, 15.6, 13.9, 13.2; HRESIMS $m / z$ $531.1961[\mathrm{M}+\mathrm{Na}]\left(\right.$ calcd for $\left.\mathrm{C}_{29} \mathrm{H}_{32} \mathrm{O}_{8} \mathrm{Na}, 531.1995\right)$; HPLC $t_{\mathrm{R}}=$ $8.260 \mathrm{~min}$; purity $=98 \%$.

3,6-Epoxy-3-methyl-3,6-dihydrotribenzocycloheptatrienone (10b). A solution of dibenzosuberenone ( $500 \mathrm{mg}, 2.4 \mathrm{mmol})$ and $\mathrm{Br}_{2}$ (774 mg, $4.8 \mathrm{mmol})$ in $\mathrm{CH}_{2} \mathrm{Cl}_{2}(100 \mathrm{~mL})$ was allowed to stir at $-30^{\circ} \mathrm{C}$ for $2 \mathrm{~h}$, during which time a precipitate was formed. The precipitate was collected by filtration and placed in a sealed tube containing THF $(100 \mathrm{~mL})$. The resulting suspension was cooled to $0{ }^{\circ} \mathrm{C}$ and then treated with
$\mathrm{KO} t$-Bu (815 mg, $7.3 \mathrm{mmol}$ ) and 2-methylfuran (200 mg, $2.4 \mathrm{mmol})$. TLC indicated that the reaction was complete after approximately $3 \mathrm{~h}$. The solvent was removed under reduced pressure, and $\mathrm{CH}_{3} \mathrm{OH}$ was added to the residue, resulting in an off-white precipitate. The precipitate was filtered to afford $416 \mathrm{mg}$ of $\mathbf{8 b}(60 \%)$ as an off-white powder: $\mathrm{mp}$ $130-132{ }^{\circ} \mathrm{C} ;{ }^{1} \mathrm{H} \mathrm{NMR}\left(400 \mathrm{MHz}, \mathrm{CDCl}_{3}\right) \delta 8.18(2 \mathrm{H}$, ddd, $J=1.1,4.6$, $7.9 \mathrm{~Hz}), 7.84-7.76(2 \mathrm{H}, \mathrm{m}), 7.73-7.63(3 \mathrm{H}, \mathrm{m}), 7.60-7.53(2 \mathrm{H}, \mathrm{m})$, $7.43(1 \mathrm{H}, \mathrm{s}), 6.02(1 \mathrm{H}, \mathrm{d}, J=1.8 \mathrm{~Hz}), 2.22(3 \mathrm{H}, \mathrm{s}) ;{ }^{13} \mathrm{C} \mathrm{NMR}(126 \mathrm{MHz}$, $\left.\mathrm{CDCl}_{3}\right) \delta 194.0,149.8,148.4,144.1,142.0,138.1,137.0,130.3,130.2$, 130.2, 129.4, 128.3, 128.0, 127.5, 127.1, 121.8, 121.6, 92.5, 82.5, 27.7; HRESIMS $m / z 287.1055[\mathrm{M}+\mathrm{H}]$ (calcd for $\mathrm{C}_{20} \mathrm{H}_{15} \mathrm{O}_{2}, 287.1072$ ); HPLC $t_{\mathrm{R}}=32.15$ min; purity $=98 \%$.

$(2 S, 4 \mathrm{a} R, 6 \mathrm{a} R, 7 R, 9 \mathrm{~S}, 10 \mathrm{a} S, 10 \mathrm{~b} R)$-Methyl 9-acetoxy-2-(8,8a,9, 12,12a,13-hexahydro-8,13:9,12-diepoxy-5H-dibenzo[3,4:6,7]cyclohept[1,2]naphthanen-5-on-10-yl)-6a,10b-dimethyl-4, 10-dioxododecahydro- $1 \mathrm{H}$-benzo[f]isochromene-7-carboxylate (11). Compound $\mathbf{1 1}$ was synthesized as described for $\mathbf{5}$ from $\mathbf{1}$ using $8 \mathrm{a}^{38}$ to afford $43.2 \mathrm{mg}$ of the exo and endo isomers of $\mathbf{1 1}(32 \%)$ as a white powder: $\mathrm{mp} 211-214{ }^{\circ} \mathrm{C}$; ${ }^{1} \mathrm{H}$ NMR (500 NMR, $\left.\mathrm{CDCl}_{3}\right) \delta 8.12$ $(5 \mathrm{H}, \mathrm{ddd}, J=1.2,6.8,12.3 \mathrm{~Hz}), 7.74-7.64(6 \mathrm{H}, \mathrm{m}), 7.55(4 \mathrm{H}, \mathrm{d}, J=$ $7.5 \mathrm{~Hz}), 7.51-7.44(3 \mathrm{H}, \mathrm{m}), 7.40(3 \mathrm{H}, \mathrm{d}, J=7.9 \mathrm{~Hz}), 6.18(1 \mathrm{H}, \mathrm{d}, J=$ $2.1 \mathrm{~Hz}), 6.11(2 \mathrm{H}, \mathrm{t}, J=2.0 \mathrm{~Hz}), 5.32(2 \mathrm{H}, \mathrm{s}), 5.23-5.21(3 \mathrm{H}, \mathrm{m}), 5.14$ $(2 \mathrm{H}, \mathrm{s}), 3.73(5 \mathrm{H}, \mathrm{s}), 3.69(3 \mathrm{H}, \mathrm{s}), 3.06-2.97(5 \mathrm{H}, \mathrm{m}), 2.82-2.57(7 \mathrm{H}$, m), $2.31(5 \mathrm{H}, \mathrm{dd}, J=7.5,14.8 \mathrm{~Hz}), 2.20(4 \mathrm{H}, \mathrm{d}, J=2.5 \mathrm{~Hz}), 2.18(4 \mathrm{H}, \mathrm{s})$, $2.14-2.08(3 \mathrm{H}, \mathrm{m}), 2.05-2.00(2 \mathrm{H}, \mathrm{m}), 1.45(3 \mathrm{H}, \mathrm{s}), 1.43(4 \mathrm{H}, \mathrm{s}), 1.11$ $(2 \mathrm{H}, \mathrm{s}), 1.10(2 \mathrm{H}, \mathrm{s}) ;{ }^{13} \mathrm{C} \mathrm{NMR}\left(126 \mathrm{MHz}, \mathrm{CDCl}_{3}\right) \delta 199.9,199.6$, $191.7,191.6,169.20,169.19,168.9,168.7,167.7,145.9,145.6,142.72$, $142.69,142.2,136.2$ (2C), 136.04, 136.01, 129.7 (2C), 129.6, 129.44, $129.38,128.24,128.22,128.1,128.0,127.7,127.6(2 \mathrm{C}), 126.72,126.70$, $126.65,126.6,125.6,125.2,122.7,122.6,122.3,122.2,78.5,78.3,78.1$, $77.7,77.2,76.9,76.5,74.8,74.6,74.4,72.7,72.64,72.60,70.8,61.9,61.6$, 51.1, 51.0, 49.61, 49.56, 48.70, 48.69, 47.9, 47.8, 47.4, 47.2, 39.7, 39.6, 39.0, 38.3, 35.7, 35.5, 33.0, 32.7, 28.4, 18.3, 18.2, 15.8, 15.7, 14.0, 13.9, 13.3, 12.9; HRESIMS $m / z 727.2549[\mathrm{M}+\mathrm{Na}]$ (calcd for $\mathrm{C}_{42} \mathrm{H}_{40} \mathrm{O}_{10^{-}}$ $\mathrm{Na}, 727.2519)$; HPLC $t_{\mathrm{R}}=5.657 \mathrm{~min}$; purity $=>99 \%$.

$(2 S, 4 a R, 6 a R, 7 R, 9 S, 10 \mathrm{a} S, 10 \mathrm{~b} R)$-Methyl 9-acetoxy-2-(8,8a, 9,12,12a,13-hexahydro-8-methyl-8,13:9,12-diepoxy-5H-dibenzo[3,4:6,7]cyclohept[1,2]naphthanen-5-on-10-yl)-6a,10bdimethyl-4,10-dioxododecahydro- $1 \mathrm{H}$-benzo[f] isochromene7-carboxylate (12). Compound $\mathbf{1 2}$ was synthesized as described for 5 from 1 using $9 \mathbf{b}$ to afford $14.2 \mathrm{mg}$ of $\mathbf{1 2}(26 \%)$ as a white powder, $\mathrm{mp}$ 198$200{ }^{\circ} \mathrm{C}(\mathrm{dec}) ;{ }^{1} \mathrm{H} \mathrm{NMR}\left(500 \mathrm{MHz}, \mathrm{CDCl}_{3}\right) \delta 7.97(2 \mathrm{H}, \mathrm{d}, J=7.8 \mathrm{~Hz})$, $7.65(1 \mathrm{H}, \mathrm{dt}, J=1.4,7.5 \mathrm{~Hz}), 7.59(1 \mathrm{H}, \mathrm{m}), 7.52(3 \mathrm{H}, \mathrm{d}, J=8.7 \mathrm{~Hz}), 7.43$ $(1 \mathrm{H}, \mathrm{d}, J=7.32 \mathrm{~Hz}), 6.17(2 \mathrm{H}, \mathrm{t}, J=1.9 \mathrm{~Hz}), 5.21(3 \mathrm{H}, \mathrm{m}), 5.05(2 \mathrm{H}, \mathrm{s})$, $3.73(3 \mathrm{H}, \mathrm{s}), 3.17(3 \mathrm{H}, \mathrm{m}), 2.76(2 \mathrm{H}, \mathrm{dd}, J=10.8,6.1 \mathrm{~Hz}), 2.63(1 \mathrm{H}, \mathrm{dd}$, 13.3, 5.8 Hz), $2.31(2 \mathrm{H}, \mathrm{m}), 2.18(3 \mathrm{H}, \mathrm{s}), 1.81(1 \mathrm{H}, \mathrm{s}), 1.70(3 \mathrm{H}, \mathrm{s}), 1.59$ $(1 \mathrm{H}, \mathrm{m}), 1.42(3 \mathrm{H}, \mathrm{s}), 1.26(2 \mathrm{H}, \mathrm{s}), 1.11(3 \mathrm{H}, \mathrm{s}) ;{ }^{13} \mathrm{C} \mathrm{NMR}(126 \mathrm{MHz}$, $\left.\mathrm{CDCl}_{3}\right) \delta 201.4,194.9,171.6,170.7,169.5,148.0,147.2,146.2,138.8$, $131.7,130.8,129.8,129.6,129.3,129.1,129.0,128.5,128.4,124.7,123.9$, 88.8, 79.5, 79.3, 78.5, 77.6, 75.01, 74.98, 64.4, 53.5, 53.0, 52.5, 52.0, 51.0, 42.1, 41.5, 38.1, 35.4, 30.8, 20.6, 18.2, 17.5, 16.3, 15.7; HRESIMS $m / z$ $741.2693[\mathrm{M}+\mathrm{Na}]\left(\right.$ calcd for $\left.\mathrm{C}_{43} \mathrm{H}_{42} \mathrm{O}_{10} \mathrm{Na}, 741.2676\right)$; HPLC $t_{\mathrm{R}}=$ $10.938 \mathrm{~min}$; purity $=99 \%$.

Diethyl 4-((2S,4aR,6aR,7R,9S,10aS,10bR)-9-acetoxy-7-(methoxycarbonyl)-6a,10b-dimethyl-4,10-dioxododecahydro$1 \mathrm{H}$-benzo[f]isochromen-2-yl)phthalate (13). A solution of 5 (100 mg, $0.17 \mathrm{mmol}$ ), $\mathrm{Fe}_{2}(\mathrm{CO})_{9}(150 \mathrm{mg}, 0.41 \mathrm{mmol}$ ), and toluene (15 mL) was allowed to stir at $60^{\circ} \mathrm{C}$ for $20 \mathrm{~min}$. Once the solution turned black, it was gradually heated to reflux and allowed to stir for $2 \mathrm{~h}$. The solution was filtered through a pad of Celite, and the solvent was removed under reduced pressure. The residue was purified by column chromatography (eluent: $50 \%$ EtOAc/50\% $n$-hexanes) to afford $55 \mathrm{mg}$ of $13(70 \%)$ as a white powder: $\mathrm{mp} 110-112{ }^{\circ} \mathrm{C} ;{ }^{1} \mathrm{H}$ NMR (500 NMR MHz, $\left.\mathrm{CDCl}_{3}\right) \delta 7.73(1 \mathrm{H}, \mathrm{d}, J=8.0 \mathrm{~Hz}), 7.62(1 \mathrm{H}, \mathrm{d}, J=1.8 \mathrm{~Hz}), 7.43(1 \mathrm{H}, \mathrm{dd}$, 
$J=1.7,8.1 \mathrm{~Hz}), 5.60(1 \mathrm{H}, \mathrm{dd}, J=5.1,11.9 \mathrm{~Hz}), 5.12-5.06(1 \mathrm{H}, \mathrm{m})$, $4.40-4.33(4 \mathrm{H}, \mathrm{m}), 3.73(3 \mathrm{H}, \mathrm{s}), 2.73(1 \mathrm{H}, \mathrm{dd}, J=6.3,10.5 \mathrm{~Hz}), 2.55$ $(1 \mathrm{H}, \mathrm{dd}, J=5.1,13.6 \mathrm{~Hz}), 2.33-2.26(2 \mathrm{H}, \mathrm{m}), 2.19(1 \mathrm{H}, \mathrm{s}), 2.16(3 \mathrm{H}$, s), $2.14(1 \mathrm{H}, \mathrm{s}), 2.12(1 \mathrm{H}, \mathrm{d}, J=3.1 \mathrm{~Hz}), 1.81(1 \mathrm{H}, \mathrm{d}, J=13.2 \mathrm{~Hz}), 1.72-$ $1.62(1 \mathrm{H}, \mathrm{m}), 1.58(1 \mathrm{H}, \mathrm{s}), 1.50(3 \mathrm{H}, \mathrm{d}, J=8.0 \mathrm{~Hz}), 1.47-1.42(1 \mathrm{H}, \mathrm{m})$, $1.37(6 \mathrm{H}, \mathrm{q}, J=7.1 \mathrm{~Hz}), 1.13(3 \mathrm{H}, \mathrm{s}) ;{ }^{13} \mathrm{C}$ NMR $\left(126 \mathrm{MHz}, \mathrm{CDCl}_{3}\right)$ $\delta$ 201.7, 171.2, 170.6, 169.5, 167.1, 166.7, 143.3, 132.8, 131.4, 129.2, $127.3,125.3,77.5,74.6,63.5,61.5,61.4,53.2,51.7,51.3,44.8,41.8,37.8$, $35.5,30.4,22.4,20.2,17.8,16.1,13.80,13.78$; HRESIMS $m / z 609.2332$ $[\mathrm{M}+\mathrm{Na}]\left(\right.$ calcd for $\left.\mathrm{C}_{31} \mathrm{H}_{38} \mathrm{O}_{11} \mathrm{Na}, 609.2314\right)$; $\mathrm{HPLC} t_{\mathrm{R}}=11.978 \mathrm{~min}$; purity $=>99 \%$.

Dimethyl 4-((2S,4aR,6aR,7R,9S,10aS,10bR)-9-acetoxy-7-(methoxycarbonyl)-6a,10b-dimethyl-4,10-dioxododecahydro$1 H$-benzo[f] isochromen-2-yl)phthalate (14). Compound 14 was synthesized as described for 13 from 6 to afford $55.2 \mathrm{mg}$ of $\mathbf{1 4}(77 \%)$ as a white powder: $\mathrm{mp} 116-119{ }^{\circ} \mathrm{C} ;{ }^{1} \mathrm{H} \mathrm{NMR}\left(500 \mathrm{MHz}, \mathrm{CDCl}_{3}\right) \delta$ $7.73(1 \mathrm{H}, \mathrm{d}, J=8.0 \mathrm{~Hz}), 7.64(1 \mathrm{H}, \mathrm{s}), 7.45(1 \mathrm{H}, \mathrm{d}, J=7.9 \mathrm{~Hz}), 5.60(1 \mathrm{H}$, $\mathrm{d}, J=6.9 \mathrm{~Hz}), 5.13-5.06(1 \mathrm{H}, \mathrm{m}), 3.91(3 \mathrm{H}, \mathrm{s}), 3.91(3 \mathrm{H}, \mathrm{s}), 3.73(3 \mathrm{H}$, s), $2.72(1 \mathrm{H}, \mathrm{d}, J=6.3 \mathrm{~Hz}), 2.55(1 \mathrm{H}, \mathrm{d}, J=8.5 \mathrm{~Hz}), 2.31(2 \mathrm{H}, \mathrm{d}, J=9.8$ $\mathrm{Hz}), 2.22(1 \mathrm{H}, \mathrm{s}), 2.19(1 \mathrm{H}, \mathrm{s}), 2.16(3 \mathrm{H}, \mathrm{s}), 2.12(1 \mathrm{H}, \mathrm{s}), 1.81(1 \mathrm{H}, \mathrm{d}$, $J=13.2 \mathrm{~Hz}), 1.66(1 \mathrm{H}, \mathrm{s}), 1.59(2 \mathrm{H}, \mathrm{s}), 1.51(3 \mathrm{H}, \mathrm{s}), 1.13(3 \mathrm{H}, \mathrm{s}) ;{ }^{13} \mathrm{C}$ NMR $\delta 200.1,169.6,169.0,168.0,165.8,165.5,141.9,130.9,129.5$, 127.6, 126.0, 123.8, 75.9, 73.1, 62.0, 51.7, 50.9, 50.8, 50.1, 49.7, 43.2, 40.2, 36.2, 33.9, 28.8, 18.7, 16.2, 14.5, 13.3; HRESIMS $m / z$ 581.1994 [M $+\mathrm{Na}$ ] (calcd for $\mathrm{C}_{29} \mathrm{H}_{34} \mathrm{O}_{11} \mathrm{Na}, 581.1999$ ); HPLC $t_{\mathrm{R}}=4.103 \mathrm{~min}$; purity $=96 \%$.

$(2 \mathrm{~S}, 4 \mathrm{a} R, 6 \mathrm{a} R, 7 R, 9 \mathrm{~S}, 10 \mathrm{a} S, 10 \mathrm{~b} R)$-Methyl 9-acetoxy-6a,10bdimethyl-2-(naphthalen-2-yl)-4,10-dioxododecahydro-1 $H$ benzo[f]isochromene-7-carboxylate (15). Compound 15 was synthesized as described for $\mathbf{1 5}$ from 7 to afford $41 \mathrm{mg}$ of $\mathbf{1 5}(70 \%)$ as a white powder: $\mathrm{mp} 240-242{ }^{\circ} \mathrm{C}$; ${ }^{1} \mathrm{H}$ NMR $\left(500 \mathrm{MHz}, \mathrm{CDCl}_{3}\right) \delta 7.82$ $(3 \mathrm{H}, \mathrm{dd}, J=7.2,12.6 \mathrm{~Hz}), 7.75(1 \mathrm{H}, \mathrm{s}), 7.51-7.46(2 \mathrm{H}, \mathrm{m}), 7.38(1 \mathrm{H}$, d, $J=1.8 \mathrm{~Hz}), 5.72(1 \mathrm{H}, \mathrm{dd}, J=5.2,11.8 \mathrm{~Hz}), 5.11-5.06(1 \mathrm{H}, \mathrm{m}), 3.73$ $(3 \mathrm{H}, \mathrm{s}), 2.76-2.70(1 \mathrm{H}, \mathrm{m}), 2.62(1 \mathrm{H}, \mathrm{dd}, J=5.3,13.6 \mathrm{~Hz}), 2.30(2 \mathrm{H}$, $\mathrm{dd}, J=5.8,13.1 \mathrm{~Hz}), 2.22(3 \mathrm{H}, \mathrm{s}), 2.16(2 \mathrm{H}, \mathrm{d}, J=4.2 \mathrm{~Hz}), 2.15(3 \mathrm{H}, \mathrm{s})$, $1.81(1 \mathrm{H}, \mathrm{s}), 1.63(1 \mathrm{H}, \mathrm{s}), 1.55(3 \mathrm{H}, \mathrm{s}), 1.14(3 \mathrm{H}, \mathrm{s}) ;{ }^{13} \mathrm{C}$ NMR $(126$ $\left.\mathrm{MHz} \mathrm{CDCl}_{3}\right) \delta 200.2,169.7,169.6,168.1,135.6,131.3,131.2,126.8$, $126.2,125.9,124.6,124.5,122.6,121.3,74.9,73.2,62.2,51.8,50.2,49.8$, 43.6, 40.3, 36.4, 34.0, 28.9, 27.9, 18.7, 16.4, 14.6; HRESIMS $\mathrm{m} / \mathrm{z}$ $515.1949[\mathrm{M}+\mathrm{Na}]\left(\right.$ calcd for $\left.\mathrm{C}_{29} \mathrm{H}_{32} \mathrm{O}_{7} \mathrm{Na}, 515.1945\right)$; HPLC $t_{\mathrm{R}}=$ $9.175 \mathrm{~min}$; purity $=>99 \%$.

$(2 \mathrm{~S}, 4 \mathrm{a} R, 6 \mathrm{a} R, 7 R, 9 \mathrm{~S}, 10 \mathrm{a} S, 10 \mathrm{~b} R)$-Methyl 9-acetoxy-2-(5-(ethoxycarbonyl)-6-(trifluoromethyl)-7-oxabicyclo[2.2.1] hepta-2, 5-dien-2-yl)-6a,10b-dimethyl-4,10-dioxododecahydro- $1 \mathrm{H}$ benzo[f]isochromene-7-carboxylate (16a) and $(2 S, 4 \mathrm{a} R, 6 \mathrm{a} R$, $7 R, 9 S, 10 \mathrm{aS}, 10 \mathrm{~b} R$ )-Methyl 9-acetoxy-2-(6-(ethoxycarbonyl)5-(trifluoromethyl)-7-oxabicyclo[2.2.1] hepta-2,5-dien-2-yl)6a, 10b-dimethyl-4,10-dioxododecahydro- $1 \mathrm{H}$-benzo[f $]$ isochromene-7-carboxylate (16b). Compounds $16 \mathrm{a}$ and $16 \mathrm{~b}$ were synthesized as described for $\mathbf{5}$ from $\mathbf{1}$ using ethyl 4,4,4-trifluoro-2-butynoate to afford $402 \mathrm{mg}$ of $16 \mathrm{a}$ and $\mathbf{1 6 b}(48 \%)$ as a white powder: $\mathrm{mp} 119-121{ }^{\circ} \mathrm{C}$; ${ }^{1} \mathrm{H} \mathrm{NMR}\left(500 \mathrm{MHz}, \mathrm{CDCl}_{3}\right) \delta 6.91(1 \mathrm{H}, \mathrm{dd}, J=1.9,3.9 \mathrm{~Hz}), 5.76(1 \mathrm{H}, \mathrm{s})$, $5.64(1 \mathrm{H}, \mathrm{dt}, J=1.8,5.5 \mathrm{~Hz}), 5.61(1 \mathrm{H}, \mathrm{s}), 5.39(1 \mathrm{H}, \mathrm{dd}, J=4.7,11.0 \mathrm{~Hz})$, $5.33-5.27(1 \mathrm{H}, \mathrm{m}), 5.15(1 \mathrm{H}, \mathrm{dd}, J=11.0,19.9 \mathrm{~Hz}), 4.35-4.23(3 \mathrm{H}, \mathrm{m})$, $3.73(4 \mathrm{H}, \mathrm{s}), 2.79-2.72(1 \mathrm{H}, \mathrm{m}), 2.43(1 \mathrm{H}, \mathrm{td}, J=5.4,13.3 \mathrm{~Hz}), 2.31(2 \mathrm{H}$, $\mathrm{dd}, J=4.3,10.6 \mathrm{~Hz}), 2.17(5 \mathrm{H}, \mathrm{d}, J=2.5 \mathrm{~Hz}), 2.13(1 \mathrm{H}, \mathrm{s}), 2.09(1 \mathrm{H}, \mathrm{d}, J=$ $8.7 \mathrm{~Hz}), 2.03(1 \mathrm{H}, \mathrm{d}, J=12.3 \mathrm{~Hz}), 1.78(1 \mathrm{H}, \mathrm{d}, J=10.1 \mathrm{~Hz}), 1.61(5 \mathrm{H}, \mathrm{dd}$, $J=12.4,21.2 \mathrm{~Hz}), 1.54-1.46(2 \mathrm{H}, \mathrm{m}), 1.41(4 \mathrm{H}, \mathrm{s}), 1.37-1.29(4 \mathrm{H}, \mathrm{m})$, $1.11(4 \mathrm{H}, \mathrm{s}) ;{ }^{13} \mathrm{C} \mathrm{NMR}\left(126 \mathrm{MHz}, \mathrm{CDCl}_{3}\right) \delta 202.0,171.54,171.53,170.7$, $170.4,170.0,169.9,162.0,161.5,158.5,157.9,151.3\left(\mathrm{q},{ }^{3} J_{\mathrm{CF}}=4.66\right), 151.0$ $\left(\mathrm{q},{ }^{2} J_{\mathrm{CF}}=35.57\right), 150.8\left(\mathrm{q},{ }^{3} J_{\mathrm{CF}}=4.87\right), 137.4,135.8,121.5\left(\mathrm{q},{ }^{1} J_{\mathrm{CF}}=\right.$ 269.57), $121.4\left(\mathrm{q},{ }^{1} J_{\mathrm{CF}}=269.63\right), 85.7\left(\mathrm{~d},{ }^{3} J_{\mathrm{CF}}=2.67\right), 84.5\left(\mathrm{~d},{ }^{3} J_{\mathrm{CF}}=\right.$ 2.52), 75.0, 74.9, 73.9, 72.7, 64.0, 64.0, 62.2, 62.1, 53.50, 53.47, 52.0, 51.2, 51.0, 42.04, 41.99, 41.1, 40.4, 38.02, 37.96, 35.5, 35.3, 30.8, 30.7, 20.61,
20.58, 18.12, 18.08, 16.4, 15.3, 15.1, 13.9; HRESIMS $m / z 621.1986[\mathrm{M}+$ $\mathrm{Na}$ ] (calcd for $\mathrm{C}_{29} \mathrm{H}_{33} \mathrm{~F}_{3} \mathrm{O}_{10} \mathrm{Na}, 621.1924$ ); analytical HPLC 16a $t_{\mathrm{R}}=$ $12.858 \mathrm{~min}$; ratio $=91 \%$; $16 \mathrm{~b} t_{\mathrm{R}}=11.759 \mathrm{~min}$; ratio $=9 \%$.

$(2 S, 4 \mathrm{a} R, 6 \mathrm{a} R, 7 R, 9 \mathrm{~S}, 10 \mathrm{a} S, 10 \mathrm{~b} R)$-Methyl 9-acetoxy-2-(3-(ethoxycarbonyl)-4-(trifluoromethyl)phenyl)-6a,10b-dimethyl-4, 10-dioxododecahydro- $1 \mathrm{H}$-benzo[f]isochromene-7-carboxylate (17a) and $(2 S, 4 \mathrm{a} R, 6 \mathrm{a} R, 7 R, 9 S, 10 \mathrm{a} S, 10 \mathrm{~b} R)$-Methyl 9-acetoxy-2-(4-(ethoxycarbonyl)-3-(trifluoromethyl)phenyl)6a,10b-dimethyl-4,10-dioxododecahydro-1H-benzo[f]isochromene-7-carboxylate (17b). A solution of $16 \mathrm{a}$ and $16 \mathbf{b}(200 \mathrm{mg}$, $0.33 \mathrm{mmol}), \mathrm{Fe}_{2}(\mathrm{CO})_{9}(150 \mathrm{mg}, 0.41 \mathrm{mmol})$, and toluene $(15 \mathrm{~mL})$ was allowed to stir at $60^{\circ} \mathrm{C}$ for $20 \mathrm{~min}$. Once the solution turned black, it was gradually heated to reflux and allowed to stir for $2 \mathrm{~h}$. The solution was filtered through a pad of Celite, and solvent was removed under reduced pressure. The residue was purified by column chromatography (gradient eluent: $10 \% \mathrm{EtOAc} / 90 \% n$-hexanes to $30 \% \mathrm{EtOAc} / 70 \% n$-hexanes) to afford $121 \mathrm{mg}$ of $\mathbf{1 7 a}(62 \%)$ and $8.2 \mathrm{mg}$ of $\mathbf{1 7} \mathbf{b}(4.2 \%)$.

17a: white powder; mp $110-112{ }^{\circ} \mathrm{C} ;{ }^{1} \mathrm{HNMR}\left(500 \mathrm{MHz}, \mathrm{CDCl}_{3}\right) \delta$ $7.72(1 \mathrm{H}, \mathrm{d}, J=8.2 \mathrm{~Hz}), 7.69(1 \mathrm{H}, \mathrm{s}), 7.50(1 \mathrm{H}, \mathrm{d}, J=8.0 \mathrm{~Hz}), 5.62(1 \mathrm{H}$, $\mathrm{dd}, J=5.0,12.0 \mathrm{~Hz}), 5.13-5.06(1 \mathrm{H}, \mathrm{m}), 4.40(2 \mathrm{H}, \mathrm{q}, J=6.9 \mathrm{~Hz}), 3.73$ $(3 \mathrm{H}, \mathrm{s}), 2.75-2.71(1 \mathrm{H}, \mathrm{m}), 2.56(1 \mathrm{H}, \mathrm{dd}, J=5.1,13.6 \mathrm{~Hz}), 2.30(2 \mathrm{H}$, $\mathrm{dd}, J=7.8,13.5 \mathrm{~Hz}), 2.24-2.18(1 \mathrm{H}, \mathrm{m}), 2.16(3 \mathrm{H}, \mathrm{s}), 2.13(2 \mathrm{H}, \mathrm{d}, J=$ $8.3 \mathrm{~Hz}), 1.82(1 \mathrm{H}, \mathrm{d}, J=13.2 \mathrm{~Hz}), 1.66(2 \mathrm{H}, \mathrm{dd}, J=14.2,26.0 \mathrm{~Hz}), 1.52$ $(3 \mathrm{H}, \mathrm{s}), 1.49-1.43(1 \mathrm{H}, \mathrm{m}), 1.39(3 \mathrm{H}, \mathrm{t}, J=7.2 \mathrm{~Hz}), 1.13(3 \mathrm{H}, \mathrm{s}) ;{ }^{13} \mathrm{C}$ NMR $\left(126 \mathrm{MHz}, \mathrm{CDCl}_{3}\right) \delta 202.0,171.5,170.8,169.9,166.5,144.4$, $132.2\left(\mathrm{q},{ }^{3} J_{\mathrm{CF}}=1.80\right), 128.4\left(\mathrm{q},{ }^{2} J_{\mathrm{CF}}=32.99\right), 127.8,127.2\left(\mathrm{q},{ }^{3} J_{\mathrm{CF}}=\right.$ 5.20), 127.0, $123.2\left(\mathrm{q},{ }^{1} J_{\mathrm{CF}}=273.41\right), 77.6,75.0,63.8,62.3,53.6,52.0$, 51.6, 45.1, 42.1, 38.1, 35.8, 30.7, 20.6, 18.1, 16.4, 15.2, 13.9; HRESIMS $m / z 605.1959[\mathrm{M}+\mathrm{Na}]\left(\right.$ calcd for $\left.\mathrm{C}_{29} \mathrm{H}_{33} \mathrm{~F}_{3} \mathrm{O}_{9}, 605.1974\right) ; \mathrm{HPLC} t_{\mathrm{R}}=$ $16.767 \mathrm{~min}$; purity $=>99 \%$.

17b: white powder; mp $100-102{ }^{\circ} \mathrm{C} ;{ }^{1} \mathrm{H} \mathrm{NMR}\left(500 \mathrm{MHz}, \mathrm{CDCl}_{3}\right)$ $\delta 7.78(1 \mathrm{H}, \mathrm{d}, J=8.0 \mathrm{~Hz}), 7.66(1 \mathrm{H}, \mathrm{s}), 7.51(1 \mathrm{H}, \mathrm{d}, J=8.0 \mathrm{~Hz}), 5.62$ $(1 \mathrm{H}, \mathrm{dd}, J=5.0,12.0 \mathrm{~Hz}), 5.12-5.07(1 \mathrm{H}, \mathrm{m}), 4.39(2 \mathrm{H}, \mathrm{q}, J=7.1 \mathrm{~Hz})$, $3.73(3 \mathrm{H}, \mathrm{s}), 2.78-2.71(1 \mathrm{H}, \mathrm{m}), 2.55(1 \mathrm{H}, \mathrm{dd}, J=5.1,13.6 \mathrm{~Hz}), 2.30$ $(2 \mathrm{H}, \mathrm{dd}, J=7.7,13.5 \mathrm{~Hz}), 2.21(1 \mathrm{H}, \mathrm{d}, J=13.9 \mathrm{~Hz}), 2.17(3 \mathrm{H}, \mathrm{d}, J=$ $5.8 \mathrm{~Hz}), 1.82(1 \mathrm{H}, \mathrm{d}, J=13.2 \mathrm{~Hz}), 1.69(1 \mathrm{H}, \mathrm{d}, J=14.4 \mathrm{~Hz}), 1.60(3 \mathrm{H}, \mathrm{s})$, $1.52(3 \mathrm{H}, \mathrm{s}), 1.46(1 \mathrm{H}, \mathrm{t}, J=12.8 \mathrm{~Hz}), 1.38(3 \mathrm{H}, \mathrm{t}, J=7.1 \mathrm{~Hz}), 1.14(3 \mathrm{H}$, s); ${ }^{13} \mathrm{C} \mathrm{NMR}\left(126 \mathrm{MHz}, \mathrm{CDCl}_{3}\right) \delta 202.0,171.5,170.8,169.9,166.4$, $143.7,131.3\left(\mathrm{q},{ }^{3} J_{\mathrm{CF}}=1.83\right), 130.8,129.4\left(\mathrm{q},{ }^{2} J_{\mathrm{CF}}=32.66\right), 128.6,123.7$ $\left(\mathrm{q},{ }^{3} J_{\mathrm{CF}}=5.38\right), 123.1\left(\mathrm{q},{ }^{1} J_{\mathrm{CF}}=273.83\right), 77.7,75.0,63.8,62.2,53.6$, 52.1, 51.7, 45.1, 42.1, 38.1, 35.9, 30.7, 20.6, 18.1, 16.5, 15.2, 13.9; HRESIMS $m / z$ 605.1979 [M $+\mathrm{Na}]$ (calcd for $\mathrm{C}_{29} \mathrm{H}_{33} \mathrm{~F}_{3} \mathrm{O}_{9}, 605.1974$ ); HPLC $t_{\mathrm{R}}=16.705 \mathrm{~min}$; purity $=90 \%$.

\section{ASSOCIATED CONTENT}

Supporting Information. NMR $\left({ }^{1} \mathrm{H},{ }^{13} \mathrm{C}\right)$ and HPLC analysis of compounds $5-7$ and $\mathbf{1 1 - 1 7}$. This material is available free of charge via the Internet at http://pubs.acs.org.

\section{AUTHOR INFORMATION}

\section{Corresponding Author}

*Tel: (785) 864-3267. Fax: (785) 864-5326. E-mail: prisinza@ ku.edu.

\section{ACKNOWLEDGMENT}

The authors would like to thank the National Institute on Drug Abuse (DA018151) for financial support of ongoing research. Portions of this work were supported by the Intramural Research Program, National Institute on Drug Abuse, NIH, DHHS. The content is the sole responsibility of the authors and does not necessarily represent the official views of the 
National Institute on Drug Abuse or the National Institutes of Health.

\section{DEDICATION}

Dedicated to Professor James M. Cook on the occasion of his 65th birthday.

\section{REFERENCES}

(1) Valdes, L. J., 3rd; Diaz, J. L.; Paul, A. G. J. Ethnopharmacol. 1983, $7,287-312$.

(2) Valdes, L. J., III; Butler, W. M.; Hatfield, G. M.; Paul, A. G.; Koreeda, M. J. Org. Chem. 1984, 49, 4716-4720.

(3) Ortega, A.; Blount, J. F.; Manchand, P. S. J. Chem. Soc., Perkin Trans. 1 1982, 2505-2508.

(4) Siebert, D. J. J. Ethnopharmacol. 1994, 43, 53-56.

(5) Roth, B. L.; Baner, K.; Westkaemper, R.; Siebert, D.; Rice, K. C.; Steinberg, S.; Ernsberger, P.; Rothman, R. B. Proc. Natl. Acad. Sci. U. S. A. 2002, 99, 11934-11939.

(6) Chartoff, E. H.; Potter, D.; Damez-Werno, D.; Cohen, B. M.; Carlezon, W. A., Jr. Neuropsychopharmacology 2008, 33, 2676-2687.

(7) Morani, A. S.; Kivell, B.; Prisinzano, T. E.; Schenk, S. Pharmacol., Biochem. Behav. 2009, 94, 244-249.

(8) McCurdy, C. R.; Sufka, K. J.; Smith, G. H.; Warnick, J. E.; Nieto, M. J. Pharmacol., Biochem. Behav. 2006, 83, 109-113.

(9) Ansonoff, M. A.; Zhang, J.; Czyzyk, T.; Rothman, R. B.; Stewart, J.; Xu, H.; Zjwiony, J.; Siebert, D. J.; Yang, F.; Roth, B. L.; Pintar, J. E. J. Pharmacol. Exp. Ther. 2006, 318, 641-648.

(10) Prisinzano, T. E.; Rothman, R. B. Chem. Rev. 2008, 108, 1732-1743.

(11) Béguin, C.; Duncan, K. K.; Munro, T. A.; Ho, D. M.; Xu, W.; Liu-Chen, L.-Y.; Carlezon, W. A., Jr.; Cohen, B. M. Bioorg. Med. Chem. 2009, 17, 1370-1380.

(12) Simpson, D. S.; Lovell, K. M.; Lozama, A.; Han, N.; Day, V. W.; Dersch, C. M.; Rothman, R. B.; Prisinzano, T. E. Org. Biomol. Chem. 2009, 7, 3748-3756.

(13) Wang, Y.; Chen, Y.; Xu, W.; Lee, D. Y.; Ma, Z.; Rawls, S. M.; Cowan, A.; Liu-Chen, L. Y. J. Pharmacol. Exp. Ther. 2008, 324, 10731083.

(14) Hooker, J. M.; Munro, T. A.; Beguin, C.; Alexoff, D.; Shea, C.; Xu, Y.; Cohen, B. M. Neuropharmacology 2009, 57, 386-391.

(15) Beguin, C.; Potter, D. N.; Dinieri, J. A.; Munro, T. A.; Richards, M. R.; Paine, T. A.; Berry, L.; Zhao, Z.; Roth, B. L.; Xu, W.; Liu-Chen, L. Y.; Carlezon, W. A., Jr.; Cohen, B. M. J. Pharmacol. Exp. Ther. 2008, 324, 188-195.

(16) Kane, B. E.; McCurdy, C. R.; Ferguson, D. M. J. Med. Chem. 2008, 51, 1824-1830.

(17) Vortherms, T. A.; Mosier, P. D.; Westkaemper, R. B.; Roth,

B. L. J. Biol. Chem. 2007, 282, 3146-3156.

(18) Peterson, L. A. Drug Metab. Rev. 2006, 38, 615-626.

(19) Zhou, S.; Koh, H.-L.; Gao, Y.; Gong, Z.-y.; Lee, E. J. D. Life Sci. 2004, 74, 935-968.

(20) Kouzi, S. A.; McMurtry, R. J.; Nelson, S. D. Chem. Res. Toxicol. 1994, 7, 850-856.

(21) Druckova, A.; Marnett, L. J. Chem. Res. Toxicol. 2006, 19, 13301340.

(22) Druckova, A.; Mernaugh, R. L.; Ham, A. J.; Marnett, L. J. Chem. Res. Toxicol. 2007, 20, 1393-1408.

(23) Zhou, S. F.; Xue, C. C.; Yu, X. Q.; Wang, G. Curr. Drug. Metab. 2007, 8, 526-553.

(24) Smissman, E. E.; Nelson, W. L.; LaPidus, J. B.; Day, J. L. J. Med. Chem. 1966, 9, 458-465.

(25) Scheerer, J. R.; Lawrence, J. F.; Wang, G. C.; Evans, D. A. J. Am. Chem. Soc. 2007, 129, 8968-8969.

(26) Hagiwara, H.; Suka, Y.; Nojima, T.; Hoshi, T.; Suzuki, T. Tetrahedron 2009, 65, 4820-4825.

(27) Bentley, K. W.; Boura, A. L.; Fitzgerald, A. E.; Hardy, D. G.; McCoubrey, A.; Aikman, M. L.; Lister, R. E. Nature 1965, 206, 102-103.
(28) Kappe, C. O.; Murphree, S. S.; Padwa, A. Tetrahedron 1997, 53, 14179-14233.

(29) Zhao, Q.; Zou, C.; Hao, X. J.; Chen, Y. Z. Chin. Chem. Lett. 1999, 10, 531-532.

(30) Reddy, P. P.; Lavekar, A. G.; Babu, K. S.; Rao, R. R.; Shashidhar, J.; Shashikiran, G.; Rao, J. M. Bioorg. Med. Chem. Lett. 2010, 20, 25252528.

(31) Harding, W. W.; Schmidt, M.; Tidgewell, K.; Kannan, P.; Holden, K. G.; Dersch, C. M.; Rothman, R. B.; Prisinzano, T. E. Bioorg. Med. Chem. Lett. 2006, 16, 3170-3174.

(32) Shoji, M.; Inoue, T.; Nakao, S.; Nakamura, M.; Hayashi, Y. Angew. Chem., Int. Ed. 2002, 41, 4079-4082.

(33) Hong, V.; Kislukhin, A. A.; Finn, M. G. J. Am. Chem. Soc. 2009, 131, 9986-9994.

(34) Padwa, A. Tetrahedron 1997, 53, 14179-14233.

(35) Lautens, M.; Webster, R. Org. Lett. 2009, 11, 4688-4691.

(36) Ma, C.; Ding, H.; Zhang, Y.; Bian, M.; Yao, W. J. Org. Chem. 2008, 73, 578-584.

(37) Schafer, D.; Franke, C.; Tochtermann, W. Chem. Ber. 1968, 101, 3122-3137.

(38) Tochtermann, W.; Oppenlaender, K.; Walter, U. Chem. Ber. 1964, 97, 1318-1328.

(39) Shao, H.; Chen, X.; Wang, Z.; Lu, P. J. Phys. Chem. B 2007, 111, 10386-10396.

(40) Sasaki, T.; Kanamatsu, K.; Izizuka, K.; Ando, I. J. Org. Chem. 1976, 41, 1425-1429.

(41) Best, W.; Collins, P.; McCulloch, R.; Wege, D. Aust. J. Chem. 1982, 35, 843-848.

(42) Fontana, G.; Savona, G.; Rodríguez, B.; Dersch, C. M.; Rothman, R. B.; Prisinzano, T. E. Tetrahedron 2008, 64, 10041-10048.

(43) Tidgewell, K.; Harding, W. W.; Schmidt, M.; Holden, K. G.; Murry, D. J.; Prisinzano, T. E. Bioorg. Med. Chem. Lett. 2004, 14, 50995102. 